\title{
DEEP RECESSIONS, FAST RECOVERIES, AND FINANCIAL CRISES: EVIDENCE FROM THE AMERICAN RECORD
}

\author{
Michael D. Bordo \\ Joseph G. Haubrich \\ Working Paper 18194 \\ http://www.nber.org/papers/w18194
NATIONAL BUREAU OF ECONOMIC RESEARCH
1050 Massachusetts Avenue
Cambridge, MA 02138
June 2012

We wish to thank David Altig, Luca Benati and John Cochrane for helpful comments, and participants at the Swiss National Bank conference on Policy Challenges and Developments in Monetary Economics, at the Federal Reserve Bank of Dallas, Stanford, Claremont, UCLA, Santa Clara, UC Santa Cruz, and the Reserve Bank of New Zealand. Patricia Waiwood provided excellent research assistance. Much of this paper was written at the Federal Reserve Bank of Cleveland where Michael Bordo is a Visiting Scholar and the research was funded by the Federal Reserve Bank of Cleveland. The views expressed herein are those of the authors and do not necessarily reflect the views of the Federal Reserve Bank of Cleveland or the National Bureau of Economic Research.

NBER working papers are circulated for discussion and comment purposes. They have not been peerreviewed or been subject to the review by the NBER Board of Directors that accompanies official NBER publications.

(C) 2012 by Michael D. Bordo and Joseph G. Haubrich. All rights reserved. Short sections of text, not to exceed two paragraphs, may be quoted without explicit permission provided that full credit, including (C) notice, is given to the source. 
Deep Recessions, Fast Recoveries, and Financial Crises: Evidence from the American Record Michael D. Bordo and Joseph G. Haubrich

NBER Working Paper No. 18194

June 2012

JEL No. N1

\begin{abstract}
$\underline{\text { ABSTRACT }}$
Do steep recoveries follow deep recessions? Does it matter if a credit crunch or banking panic accompanies the recession? Moreover does it matter if the recession is associated with a housing bust? We look at the American historical experience in an attempt to answer these questions. The answers depend on the definition of a financial crisis and on how much of the recovery is considered. But in general recessions associated with financial crises are generally followed by rapid recoveries. We find three exceptions to this pattern: the recovery from the Great Contraction in the 1930s; the recovery after the recession of the early 1990s and the present recovery. The present recovery is strikingly more tepid than the 1990s. One factor we consider that may explain some of the slowness of this recovery is the moribund nature of residential investment, a variable that is usually a key predictor of recessions and recoveries.
\end{abstract}

\author{
Michael D. Bordo \\ Department of Economics \\ Rutgers University \\ New Jersey Hall \\ 75 Hamilton Street \\ New Brunswick, NJ 08901 \\ and NBER \\ bordo@econ.rutgers.edu \\ Joseph G. Haubrich \\ Federal Reserve Bank ofCleveland \\ 1455 East 6th Street \\ Cleveland, Ohio 44114 \\ jhaubrich@clev.frb.org
}




\title{
Deep Recessions, Fast Recoveries, and Financial Crises: Evidence from the American Record
}

\author{
By Michael D. Bordo and Joseph G. Haubrich*
}

\begin{abstract}
June 18, 2012.
Do steep recoveries follow deep recessions? Does it matter if a credit crunch or banking panic accompanies the recession? Moreover does it matter if the recession is associated with a housing bust? We look at the American historical experience in an attempt to answer these questions. The answers depend on the definition of a financial crisis and on how much of the recovery is considered. But in general recessions associated with financial crises are generally followed by rapid recoveries. We find three exceptions to this pattern: the recovery from the Great Contraction in the 1930s; the recovery after the recession of the early 1990s and the present recovery. The present recovery is strikingly more tepid than the 1990s. One factor we consider that may explain some of the slowness of this recovery is the moribund nature of residential investment, a variable that is usually a key predictor of recessions and recoveries.
\end{abstract}

\section{Introduction}

The recovery from the recent recession has now been proceeding for twelve quarters. Many argue that this recovery is unusually sluggish and that this reflects the severity of the financial crisis of 2007-2008 (Roubini, 2009). Yet if this is the case it seems to fly in the face of the record of U.S. business cycles in the past century and a half. Indeed, Milton Friedman noted as far back as 1964 that in the American historical record "A large contraction in output tends to be followed on the average by a large business expansion; a mild contraction, by a mild expansion." (Friedman 1969, p. 273). Much work since then has confirmed this stylized fact but has also begun to make distinctions between cycles, particularly between those that include a financial crisis. Zarnowitz (1992) documented that pre-World War II recessions accompanied by banking panics

* Bordo: Rutgers University and Hoover Institution, 434 Galvez Mall, Stanford University, Stanford, CA 94305-6010, michael.bordo@gmail.com. Haubrich: Federal Reserve Bank of Cleveland, PO Box 6387, Cleveland, OH 44101-1387, jhaubrich@clev.frb.org. The views expressed here are solely those of the authors and not necessarily those of the Federal Reserve Bank of Cleveland or the Board of Governors of the Federal Reserve System. We wish to thank David Altig, Luca Benati and John Cochrane for helpful comments, and participants at the Swiss National Bank conference on Policy Challenges and Developments in Monetary Economics, at the Federal Reserve Bank of Dallas, Stanford, Claremont, UCLA, Santa Clara, UC Santa Cruz, and the Reserve Bank of New Zealand. Patricia Waiwood provided excellent research assistance. 
tended to be more severe than average recessions and that they tended to be followed by rapid recoveries.

In this paper we revisit the issue of whether business cycles with financial crises are different. We use the evidence we gather to shed some light on the recent recovery. A full exploration of this question benefits from an historical perspective, not only to provide a statistically valid number of crises, but also to gain perspective from the differing regulatory and monetary regimes in place. We look at 27 cycles starting in 1882 and use several measures of financial crises. We compare the change in real output (real GDP) over the contraction with the growth in real output in the recovery, and test for differences between cycles with and without a financial crisis. After comparing the amplitudes, we then look at various measures of the shape of cycles, ranging from simple steepness measures to more recent tools such as Harding and Pagan's (2002) excess cumulative movement.

We then turn to more quantitative measures of financial stress and assess their impact on the shape of the resulting recovery. With both price (credit spread) and quantity (bank loan) data, finer distinctions between financial crises can be drawn. In other words, is the strength of the recovery related to either the change in lending or the credit spread? Finally, we introduce residential investment as a possible explanation for a slow recovery after a recession that involves a housing bust, as the U.S. is currently experiencing.

Our analysis of the data shows that steep expansions tend to follow deep contractions, though this depends heavily on when the recovery is measured. In contrast to much conventional wisdom, the stylized fact that deep contractions breed strong recoveries is particularly true when there is a financial crisis. In fact, on average, it is cycles without a financial crisis that show the weakest relation between contraction depth and recovery strength. For many configurations, the evidence for a robust bounce-back is stronger for cycles with financial crises than those without. The results depend somewhat on the time period, with cycles before the Federal Reserve looking different from cycles after the Second World War.

We find that measures of financial strength have some impact on the strength of recoveries. Our results also suggest that a sizeable fraction of the shortfall of the present recovery from the average experience of recoveries after deep recessions is due to the collapse of residential investment.

Though the literature on this topic is extensive, there is little work that incorporates both such a long data series and examines financial crises. Friedman, $(1969,1988)$ has a similarly long series but does not consider the effect of financial crises, in addition to using somewhat different data and empirical techniques. In contrast to most subsequent work, Friedman looks at growth over the entire expansion. Wynne and Balke $(1992,1993)$ include only cycles since 1919 and do not consider the effect of financial crises. They measure growth 4 quarters into the expansion. Lopez-Salido and Nelson (2010) explicitly look at the connection between financial crises and recovery strength but look only at post-World War II 
cycles in the US. Reinhart and Rogoff $(2008,2009)$ concentrate on major international financial crises since the Second World War, and document long and severe recessions, but make few direct comparisons of the recovery speed with noncrisis cycles. Howard, Martin and Wilson (2011) look at the relationship between recoveries and crises for 59 countries since 1970 and reach conclusions similar to ours. Bordo and Haubrich (2010) find that contractions associated with a financial crisis tend to be more severe but do not gauge the speed of the resulting recovery. Cerra and Saxena (2008) look at data for 190 countries and find that output losses in disasters are in general not recovered, in the sense of returning to the pre-crisis trend line. Gourio (2008) finds strong recoveries after disasters, in the sense of exceptionally high growth rates. Stock and Watson (2012) use a 198 variable dynamic factor model on data since the Second World War, attributing recent slow recoveries to demographic factors in the labor market. Gali, Smets and Wouters (2012) estimate a structural new Keynesian model and attribute the current slow recovery to adverse demand shocks stemming from the zero lower bound and wage markups. Hall (2011) defines a related concept of slump, when employment is below 95.5 percent of the labor force.

The remainder of the paper is as follows. Section 2 presents an historical narrative on U.S. recoveries. Section 3 examines the amplitude, duration and shape of business cycles since 1882, testing whether strong recoveries follow deep contractions, and whether financial crises alter that pattern. Section 4 looks at how credit spreads and bank lending affect the relationship between contraction depth and recovery strength. Section 5 examines the connection between weak recoveries and slow residential investment. It incorporates the long-standing importance of housing in the transmission mechanism. Section 6 concludes and offers some policy advice for the current recovery in light of the historical record.

\section{Narrative}

We present some descriptive evidence and historical narratives on U.S. business cycle recoveries from 1880 to the present. Figure 1 shows the quarterly path of GDP from the preceding peak to the trough of each business cycle and then the quarterly path of GDP from the trough for the same number of quarters that occurred in the downturn. The figure makes it easy to determine if output has returned to the level at the peak, a natural comparison point that has often been used before, such as in Romer (1984). Even so, it does not account for trend growth, or a return to any "full potential" of the economy. At some level, even very basic questions of interpretation are unresolved: Cole and Ohanian (2004) start out their paper with "The recovery from the Great Depression was weak." Friedman and Schwartz (1963, p. 493) insist that "severe contractions tend to be succeeded by vigorous rebounds. The 1929-1933 contraction was no exception."

Table 1 shows some metrics on the salient characteristics of the recessions and recoveries. Column 1 reports the date of the cyclical peak, as determined by the NBER. Column 2 measures the steepness of the drop, and column 3 shows the 
steepness of the recovery, both of which are measured as the percentage change in real GDP divided by the duration of the contraction: that is, if the contraction lasted seven quarters, we go out seven quarters into the recovery. Column 4 shows the total change (usually a drop) in GDP during the contraction, and column 5 shows the total change (usually an increase) during the recovery going out the same number of quarters as the contraction lasted. Columns 6 and 7 show the percentage changes.

Table 2 summarizes the historical experience of all U.S. business cycles since 1880. It is divided into three eras: pre-Federal Reserve; interwar; and post-World War II (panels A,B, and C). Column 1 dates the NBER trough, column 2 shows the dates of the recovery, column 3 indicates if it was a major recession; column 4 indicates whether a banking crisis occurred during the recession; column 5 indicates whether there was a credit crunch as defined in Bordo and Haubrich (2010); column 6 indicates whether there was a housing bust as indicated by Shiller (2009); and column 7 indicates whether or not there was a stock market crash. Each panel is divided into two parts, the first showing recessions cycles where the pace of the recovery was at least as rapid as the downturn. The second shows cycles where recoveries were slower than the downturn.

\section{A. 1880-1920: The Pre-Federal Reserve Period.}

During this era the U.S. was on the gold standard and did not have a central bank. The NBER demarcates 11 business cycles, of which two, 1893(I) to 1894(II) and 1907(II) to 1908(II), had major recessions. There were also 4 banking panics and 6 stock market crashes. Most of the recoveries were followed by recoveries at least as rapid as the downturns with the exception of the cycle following World War I. The key driving forces in the pre-WWI business cycles were foreign shocks, e.g. Bank of England tightening, banking instability, the state of harvests in the U.S. relative to Europe, and investment in railroads. Fels (1959) and Friedman and Schwartz (1963) have useful narratives of business cycles in this era.

The recovery of 1879 to 1882, according to Friedman and Schwartz (chapter 2 ), shows a perfect example of the operation of the price-specie-flow mechanism of the classical gold standard. Favorable harvests in the U.S. at the same time as unfavorable ones in Europe generated a large balance-of-trade surplus and gold inflows, raising the money supply and stimulating the economy. The key driver of expansion was railroad construction, continuing the boom that had been interrupted by the panic of 1873 and the resulting recession. The recession of 1882-85 featured a banking panic in May 1884 and a stock market crash. The banking panic ended with the issuance of clearinghouse loan certificates and U.S. Treasury quasi-central banking operations. The recovery of 1885 (II) to 1887 (II) was driven by capital and gold inflows. The recovery was interrupted by a brief one-year mild contraction.

The recovery from 1888(I) to 1890(III) was driven by good harvests in the U.S. and bad ones in Europe (Fels 1959). Two big shocks ended the recovery: the 
passage of the Sherman Silver Purchase Act, which led to serious capital flight based on fears that the U.S. would be forced off gold; and the Baring Crisis in London, which led to a sudden stop of capital flows to all emerging markets, including the U.S. These events culminated in a banking panic in New York, which was ended by the issuance of clearinghouse loan certificates. The recession ended in May 1891 and recovery from 1891(II) to 1893(I) was fostered by a series of good U.S. harvests, which generated gold inflows.

The decade of the 1890s was shadowed by silver uncertainty and falling global gold prices, which produced persistent deflationary pressure. The recovery ended in May 1893 with a stock market crash and a major banking panic which spread from New York City to the interior and then back. The panic led to many bank failures across the country and a monetary contraction, contributing to a serious recession. It ended with the suspension of convertibility of deposits into currency in the fall of 1893. The subsequent recovery from 1894(II) to 1895(III) was aided by the Belmont Morgan syndicate, which was created in early 1895 to rescue the US Treasury's gold reserves from a silver-induced run. Silver uncertainty contributed to capital flight and led to another recession from late 1895 to 1897. The election of 1896 was fought over the issue of free silver and once the silver advocate William Jennings Bryan was defeated, the pressure eased.

The recovery from 1897 (II) to 1899(II) began a long boom interrupted by a few minor recessions. The key drivers of the boom were important gold discoveries in Alaska and South Africa which increased the global monetary gold stock and ended the Great Deflation of the late nineteenth century. Increased gold output stimulated the real economy. A very mild recession in 1899-1900, associated with the outbreak of the Boer War, interrupted the expansion. Gold inflows and good harvests drove the recovery from 1900(I) to 1902(IV), which ended with the "rich man's panic" of 1902 and a mild recession from 1902 to 1904. The following recovery from 1904(II) to 1907(IV) was driven by heavy capital inflows from London, in part reflecting insurance claims resulting from the San Francisco earthquake (Odell and Weidenmeier 2004). The Bank of England reacted to declining gold reserves by raising its discount rate and rationed lending based on U.S. securities. This created a serious shock to U.S. financial markets, triggering a stock market crash and a major banking panic in October 1907. The banking panic led to many bank failures, a drop in the money supply and a serious recession, which ended in May 1908. The panic and recession of 1907-08 led to the monetary reform that created the Federal Reserve in 1913.

The recession of 1907-1908 was followed by a vigorous recovery from 1908(II) to 1910(I). Friedman and Schwartz attribute this to gold inflows reflecting a decline in US prices relative to those in Britain stemming from crisis. A mild recession from 1910 to 1912 triggered by capital outflows was followed by a brief recovery in 1912-1913. The onset of World War I in 1914 led to a recession and banking crisis. The recession was then followed by a major boom, driven by the demand for U.S. goods by the European belligerents and then the U.S. as it prepared for 
war.

The wartime recovery ended with a recession from 1918(III) to 1919(I) following the cessation of hostilities and the conversion from war to peace. The vigorous recovery involved a major restocking boom and rapid commodity inflation in the US. The Federal Reserve, which had opened its doors in 1914 and had become an engine of inflation subservient to the Treasury, was reluctant to raise its discount rate to fight inflation in 1919 because of concern over the Treasury's portfolio. In the face of a declining gold reserve, the Fed reluctantly tightened sharply at the end of 1919 precipitating a serious recession in 1920.

\section{B. The Interwar Period: 1920-1945}

The Federal Reserve was established in 1914 in part to solve the problem of the absence of a lender of last resort in the crises of the pre-1914 national banking era. In the Fed's first 25 years there were three very severe business cycle downturns and several minor cycles. In addition to exogenous shocks such as wars, Fed policy actions were key in both precipitating and mitigating cycles. Most of the recoveries in this period were at least as rapid as the downturns that preceded them with one important exception: the recovery from the Great Contraction of 1929 to 1933.

Recovery 1921(III) to 1923(II): The recession that followed Fed tightening in December 1920 was severe but short: industrial production fell $23 \%$, wholesale prices fell $37 \%$ and unemployment increased from $4 \%$ to $12 \%$. No banking panic occurred but the stock market crashed in the fall of 1920. In the face of mounting political pressure the Fed reversed course in November 1921 and the real economy began recovering in August 1921. By March 1922 Indusrial Production had increased $20 \%$ above the previous year's level.

Recoveries 1924(II) -1926(III) and 1927(IV) - 1929(III): Two mild recessions in the mid-1920s reflected Fed preemptory tightening in the face of incipient inflation. In each case the recessions were followed by healthy recoveries. There were no banking crises or stock market crashes in these episodes, but there was a housing bust in 1926 (White 2010).

Recovery 1933(I) - 1937(II): The Fed tightened beginning in late 1926 to stem the stock market boom which had begun that year. This tightening led to a recession in August 1929 and a major stock market crash in October. A series of banking panics beginning in October 1930 ensued. The Fed did little to offset them, turning a recession into the Great Contraction. The recovery began after Roosevelt's inauguration in March 1933 with the Banking Holiday. Other key events in spurring recoveries included the U.S. leaving the gold standard in April, Treasury gold and silver purchases, and the devaluation of the dollar by close to $60 \%$ in January 1934 . These policies produced a big reflationary impulse from gold inflows, which were unsterilized and so passed directly into the money supply. They also helped convert deflationary expectations into inflationary ones (Eggertsson 2008).Expansionary monetary policy largely explains the 
rapid growth from 1933 to 1937 (Romer 1992). As Table 2 and Figure 1 show, the recovery, although rapid (output grew by $33 \%$ ) was not sufficient to completely reverse the preceding downturn. The recovery may have been impeded somewhat by New Deal cartelization policies like the NIRA, which, in an attempt to raise wages and prices artificially reduced labor supply and aggregate supply (Cole and Ohanian 2004).

Recovery 1937(III) - 1945(I): The 1937-38 recession, which cut short the rapid recovery from the Great Contraction of 1929-1933 was the third worst recession of the twentieth century, as real GDP fell by $10 \%$ and unemployment, which had declined considerably after 1933 , increased to $20 \%$. The recession was produced by a major Fed policy error. Policymakers doubled reserve requirements in 1936 to sop up excess reserves and prevent future inflation. The Fed's contractionary policy action was complemented by the Treasury's decision in late June 1936 to sterilize gold inflows in order to reduce excess reserves. These policies led to a collapse in money supply and a return to a severe recession (Friedman and Schwartz 1963, Meltzer 2003). Fiscal policy hardly helped, with the Social Security payroll tax debuting in 1937 on top of the tax increase mandated by the Revenue Act of 1935 (Hall and Ferguson, 1998).

The recession ended after FDR in April 1938 pressured the Fed to roll back reserve requirements, the Treasury stopped sterilizing gold inflows and desterilized all remaining gold sterilized since December 1936 and the Administration began pursuing expansionary fiscal policy. The recovery from 1938 to 1942 was spectacular: output grew by $49 \%$ fueled by gold inflows from Europe and a major defense buildup.

\section{Post-World War II: 1945 -2011}

In the post-World War II era, with only two exceptions, recoveries were at least as rapid as the downturn. In general recessions were shorter and recoveries longer than before World War II (Zarnowitz 1992). There also were fewer stock market crashes. The key exceptions to this pattern were the recovery of 1991(I) -2001(I) and the recent recovery which started in 2009(II). The recent recession was the only one with a banking crisis, stock market crash and housing bust.

1945(IV) -1948(IV). The conversion from a wartime to a peacetime economy led to a very sharp, quick recession followed by a very rapid recovery. The recovery ended in 1948 with Fed tightening to fight inflation, leading to a mild recession from 1948 to 1949.

1949(IV) -1953(II). According to Meltzer (2003, chapter 7) the rapid recovery from the 1948-49 recession was aided by deflation, which encouraged gold inflows and increased the real value of the monetary base.

1954(III)- 1953(II). After the Federal Reserve Treasury Accord of March 1951, the Fed was free again to use its policy rates to pursue its policy aims. At the end of the Korean War, it tightened policy to stem inflation, leading to a recession beginning in July. The Fed then began easing policy well before the business cycle 
trough in May 1954, leading to a rapid recovery. Again in the face of incipient inflation the Fed began a tightening cycle at the end of 1954, which led to a recession beginning in August 1957(II) (Friedman and Schwartz 1963 chapter 11, Meltzer 2010, chapter 2).

1958(II) - 1960(II). The recession of $1957-58$ was one of the most severe recessions of the postwar period but it was very short-lived. It ended after April 1958 following expansionary policy that began in November 1957. The subsequent recovery was vigorous. Again the Fed, worrying about rising inflation and gold outflows, began tightening in August 1958. The tightening cycle ended with a recession beginning in April 1960 (Friedman and Schwartz 1963, chapter 11, Meltzer 2010, chapter 2).

1961(I) - 1969(IV). By early 1960 the FOMC recognized that the economy had slowed and began to ease two months before the April business cycle peak. The recession of 1960-61 was mild and brief, lasting 10 months. Fed policy continued to be loose throughout the downturn. The recession ended in February 1961 and the subsequent recovery exhibited very rapid growth with low inflation.

1970(IV) - 1973(IV). In face of rising inflation after 1965, the Fed began tightening. This was not enough to stem the buildup of inflation, although it led to the Credit Crunch of 1966 and a growth slowdown (Bordo and Haubrich 2010). Fed tightening in the summer of 1969 led to a mild recession beginning in July 1969. Policy began to ease after January 1970. In April 1970 Chairman Arthur Burns abandoned the anti-inflationary policy that had been pursued by his predecessor William McChesney Martin, because of the slowing economy. The easy policies continued until after the business cycle trough. Recovery in real GDP was relatively sluggish, and unemployment didn't peak until the summer of 1971 .

1975(II) - 1980(I). In the face of rising inflation in 1972, the Fed tightened but not enough (Meltzer 2010 chapter 6). Further tightening occurred in the summer of 1973. The recession which began in November was one of the worst in the postwar period. Real GDP fell by $3.4 \%$ and unemployment increased to $8.6 \%$. The recession was greatly aggravated by the first oil price shock, which doubled the price of oil, and by wage price controls which prevented the necessary adjustment. During this episode the U.S. experienced a minor banking crisis with the failure of Franklin National and other significant banks (Lopez-Salido and Nelson 2010) Beginning in July 1974 the Fed shifted to easier policy in the face of rising unemployment. The recovery began in April 1975. As in most of the postwar recessions the pace of the recovery exceeded the pace of the downturn.

1980(III) - 1981(III). By 1979 inflation had reached double digit-levels. In August, Paul Volcker was appointed chairman of the Federal Reserve. In October, he announced a major shift in policy aimed at lowering inflation. The announcement was followed by a series of sizable hikes in the federal funds rate. The roughly 7 percentage point rise in the nominal funds rate between October 1979 and April 1980 was the largest increase over a six-month period in the history of the Federal Reserve. The tight monetary stance was temporarily abandoned in mid-1980 as 
interest rates spiked and economic activity decelerated sharply. The FOMC then imposed credit controls (March to July 1980) and let the funds rate decline. The controls led to a marked decline in consumer credit, personal consumption, and a very sharp decline in economic activity. The recession ended in July 1980 and was followed by a very rapid recovery.

1981(IV) - 1990(III). Fed policy began to tighten again in May 1981 in the face of a jump in inflation. It raised the federal funds rate from $14.7 \%$ in March to $19.1 \%$ June. This second and more durable round of tightening succeeded in reducing the inflation rate from $10 \%$ in early 1981 to $4 \%$ in 1983 but at the cost of a sharp and very prolonged recession. Real GDP fell by close to $3 \%$ and unemployment increased from $7.2 \%$ to $10.8 \%$.During this period there were two minor banking crises, the first between 1982-1984 as a consequence of the Latin American debt crisis, which seriously impacted the money center banks, and the second, the Savings and Loan Crisis from 1988-1991 (Lopez-Salido and Nelson 2010). There also was a stock market crash in the fall of 1987.

The Fed shifted to a looser policy in June 1982. After the trough, real output rose rapidly, and the pace of the recovery greatly exceeded that of the downturn. The recession of 1991 was preceded by Fed policy tightening beginning in December 1988 (Romer and Romer 1994). The FOMC wanted to reduce inflation from the $4 \%$ to $4.5 \%$ range. The federal funds rate was raised from $6 \%$ to $97 / 8 \%$ between March and May. The recession began in July 1990 and was aggravated by an oil price shock after Iraq invaded Kuwait in August 1990. The recession was mild. Real GDP fell by only $1.1 \%$.

1990(I) to 2001(I). The FOMC only began cutting the funds rate in November 1990 because its primary concern was to reduce inflation which had reached $6.1 \%$ in the first half of 1990 (Hetzel 2008 chapter 15). The recovery from the trough in March 1991 was considered tepid and it was referred to as a jobless recovery. Unemployment peaked at $7.75 \%$ in June 1992. The recession was also viewed as a credit crunch (Bordo and Haubrich 2010), and real housing prices declined by $13 \%$ suggesting a minor housing bust. This is the first recovery in the post-war era where the pace of expansion was less than that in the downturn.

2001(IV) - 2007(IV). In 2000 the Fed loosened monetary policy because of the fear of Y2K. The tech boom, which had elevated the NASDAQ to unsustainable levels, led to a bust and a decline in wealth and consumption. The FOMC didn't forecast a recession and was slow to respond because of tightness in the labor market (Hetzel 2008, page 241). Although real growth began decelerating in mid-2000, the FOMC began reducing the funds rate in January 2001, from 6.5\% to $1 \%$ by June. After the trough in November, although real growth had picked up, employment had not and like the previous recession there was talk about a jobless recovery. By March 2004 the unemployment rate was at 5.7\% still near its cyclical peak. Moreover since 2003 the Fed had worried about deflation and the zero lower bound problem. Consequently the funds rate was maintained at its recession low until June 2004 when, alarmed by an increase in inflationary 
expectations, the Fed began raising the funds rate at $0.25 \%$ increments increments until late summer 2007.

2009(II) - ?. The recent recession which began in December 2007 was precipitated by a banking crisis and a stock market crash consequent on the end of a major housing boom. The severity of the resulting recession from December 2007 to the summer of 2009 reflected both a credit crunch and tight Fed policies (seen in high real federal funds rates, Hetzel 2009). The recession was the most severe in the postwar period (real GDP fell by more than $5 \%$ and unemployment increased to $10.8 \%$ ). The financial crisis in the fall of 2008 was without doubt the most serious event since the Great Contraction.

Both the crisis and the recession were dealt with by vigorous policy responses: on the monetary policy side, the Federa Reserve cut the funds rate from $5.25 \%$ in early fall 2007 to close to zero by January 2009), introduced quantitative easing via the purchase of mortgage-backed securities and long-term Treasuries from January 2009 to June 2011, and formed and an extensive network of facilities created to support the credit markets directly and reduce spread. These programs involved a tripling of the Fed's balance sheet, on top of a massive fiscal stimulus package. The recovery since 2009 has been tepid with real growth expanding at slightly above $2 \%$. The pace of recovery is well below the drop of output during the recession.

\section{The Relationship between Recessions and Recoveries}

In this section we take a more statistical view of the relationship between the depth of the contraction and the strength of the following expansion. At this point, we make no claims about causality: we do not consider here whether financial crises contribute to recessions or recessions create financial crises.

Our data is based on Bordo and Haubrich (2010), where we provide a more detailed description. Business cycle turning points (in quarters) come from the NBER. Real Gross Domestic Product, again at a quarterly frequency, is based on Balke and Gordon (1986) and Gordon and Krenn (2010), extended via the NIPA accounts. This gives us quarterly RGDP for 27 business cycles, starting with the peak in 1882 and ending with the recovery from the 2007 recession.

We measure the amplitude of the contraction by the percentage drop (from the peak) of quarterly RGDP. We measure the recovery strength as the percentage change from the trough at two horizons: four quarters after the cyclical trough and after a time equal to the duration of the contraction. Going out the length of the contraction, while it appeals to symmetry, appears to be new, as most papers restrict their attention to 4 quarters (or 12 months if they use monthly data). Friedman is the exception, looking at growth to the next cyclical peak. Morley and Piger (2012) in their discussion of bounceback models, consider recoveries of up to six quarters after a trough, while Howard, Martin and Wilson (2011) look out three years after a trough. Papell and Prodam (2011) look at when growth rates return to trend and when both levels and growth return to trend. 
Exactly what constitutes a financial crisis depends on how it is defined, and the question has been answered several ways. In this section, for the pre-World War II years we use the chronology from Bordo and Eichengreen (2002) and also add 1914, a year in which the bond markets closed. For the post war period, we use the chronology of Lopez-Salido and Nelson. This gives us crisis periods of 1884-5, 1892-93, 1895, 1904, 1907, 1914, 1930-33, 1973-75, 1982-84, 1988-91 and 2007. Consequently, the recessions we associate with a financial crisis are those that start in 1882, 1893, 1907, 1913, 1929, 1973, 1981, 1990 and 2007. (We drop the 1945 recession from our sample. This is reasonable, but it matters, as it was the deepest recession of the century outside the Great Depression, with an extremely weak recovery.) It is perhaps interesting to note that the five GDP "disasters" picked out by Barro and Jin (2011) in the US were for the cycles with troughs in 1908, 1914, 1921, 1933 and 1947, with three of those five being associated with a financial crisis. (With our data, we would add 1894 and 1938 as disasters where RGDP fell by 10 percent or more.) Interestingly, of our 27 business cycles, only 4 did not have some form of financial crises, according to the reckoning of Reinhart and Rogoff (1899, 1923, 1953 and 1960).

\section{A. Are Deep Recessions Followed by Steep Recoveries?}

The visual evidence (Figure 2) strongly suggests that deep recessions are followed by strong recoveries, though it suggests that a few outliers, particularly the Great Depression, may have a disproportionate impact. Regressing growth 4 quarters after the trough against contraction amplitude shows a positive but small and statistically insignificant relationship. The relationship is tighter, and stronger, if we examine more of the recovery, measuring growth out to the duration of the contraction after the trough. Looking out only 4 quarters can give a misleading picture, particularly for longer recessions. Much of the difference is in fact driven by the Great Depression, and it should not be surprising that the drop in output from 1929 to 1933 was not fully reversed by 1934, though the economy came much closer by 1936 .

Do financial crises affect the bounceback? The scatterplots in Figure 3 strongly suggest a difference between the recoveries in crisis and noncrisis cycles, but for reasons contrary to the conventional wisdom. In crisis times, strong recoveries follow deep recessions, but outside of a crisis, they do not. The relation is in fact negative, though not statistically significant.

To get a more formal view of the difference, we run a set of regressions based on the following specification:

$$
\% \Delta Y_{T+k}=\alpha_{1}+\alpha_{2} D_{F}+\beta_{1}\left[\% \Delta Y_{P-T}\right]+\beta_{2} D_{F}\left[\% \Delta Y_{P-T}\right] .
$$

As a baseline we also run

$$
\% \Delta Y_{T+k}=\alpha_{1}+\beta_{1}\left[\% \Delta Y_{P-T}\right] .
$$


Thus the strength of the expansion is regressed against a constant, a dummy for financial crises, a measure of the depth of the contraction and an interaction between the financial crisis dummy and the depth of the contraction. A Chow test then determines the significance of excluding the dummy and the interaction term. This specification is meant to capture two separate ways that a crisis may affect the bounceback. On average, such contractions may have a slower recovery, but the relationship between contraction depth and recovery strength may also be affected.

It may not be proper to lump all crises and all cycles together, given the very different monetary standards and regulatory regimes in place over time. We split the data several ways, dropping the Great Depression, and separately examining the years after the founding of the Federal Reserve and after the Second World War. Table 3 reports the results out to the first four quarters of the expansion, and Table 4 looks at the expansion going out the duration of the contraction.

Looking only at 4 quarters of the recovery, there is not much evidence that recoveries following financial crises are much different. At a formal level, the Chow test does not show a significant difference. Informally, the coefficient on the financial dummy is uniformly negative, indicating that recoveries following financial crises are on average somewhat smaller, though the coefficient is significant in one case. The interaction term, also insignificant, is split between negative and positive values: in the one significant case the depth of the recession has a greater impact on the strength of recoveries when there is a crisis.

The differences are more striking once more of the recovery is considered, as Table 4 shows. The interaction term and the Chow test are significant in all but the post-World War II samples. The dummy for financial crises is always negative, but it is significant only half the time. The post-World War II sample shows no significant difference between crisis and noncrisis recoveries (perhaps because crises were less severe, a point we return to later), but for the other samples a clear pattern emerges: the dummy for financial crisis is negative, but the interaction term is positive. This means that relatively mild recessions with a crisis have slower than average recoveries, but the deeper the recession, the stronger the recovery. For the entire sample, the crossover point is about $3.25 \%$, met by most crisis contractions except 1882, 1973, 1981 and 1990, which perhaps contributes to the impression that the crisis recoveries are weaker. The numbers have economic heft: a one percent deeper recession with a crisis will lead to greater than an extra one and one half percent of growth in the quarters following the trough.

Bordo and Landon-Lane (2010) find the world has had five global financial crises since 1880 (1890-91, 1907-08, 1913-14, 1930-33 and 2007-2008). Figure 4 plots recovery amplitude (4 quarters) against contraction amplitude for these crises and all post-World War II contractions, including 2007-2008.

Like the previous figures, figure 4 shows a positive relationship between contraction amplitude and recovery strength, though the coefficient is relatively small. 
In part, this arises from the three most recent cycles, which seem different, with both a lower intercept and a lower slope. Some speculation suggests that this results from changes in labor market behavior since the 1980s. (Beauchemin, 2010).

\section{B. Does "shape" matter?}

Another possible relationship between contractions and expansions concerns their shape. One obvious measure of shape is steepness, or change in output divided by duration. Tables 5 and 6 report the results of regressing the steepness of the recovery against the steepness of the contraction, again dropping 1929 and looking at post-Fed and post-World War II periods.

Steepness does pick out differences between recoveries with and without financial crises. The financial crisis dummy is significantly negative in six of eight cases, turning positive for the post-World War II period both times. So everything else equal, crisis recoveries are smaller. But everything else is not equal, for the interaction term is signficantly positive in the same six cases, while the coefficient on contraction depth is insignificant, small and generally negative. The conclusion is that crisis recoveries show a strong relationship between contraction depth and recovery strength, but the noncrisis recoveries do not. Far from overturning the stylized fact, crisis recoveries account for it!

Steepness is not the only measure of shape. For example, the contraction might be "L" shaped, that is, dropping quickly at first, but then only slowly reaching a trough. (Macroeconomic Advisors, 2009) This might be thought of as a worse contraction than one that is more linear. Or, the cycle might have a "V" shape or a "U" shape or some other imaginative denotations-the 2007 cycle has at times been described as having a "square root sign" shape.

Quantifying shape beyond mere steepness may seem a daunting task, but Harding and Pagan (2002) have a useful approach. They measure the extent to which the drop in output during the contraction deviates from a straight line and develop an index of excess cumulated movements. Several specifications, however, have not uncovered any meaningful relationship between the shape of the contraction and the shape of the recovery.

\section{Bank Lending and Credit Crunches}

Designating a time period as having a crisis or not is in some ways an unsubtle approach to the problem-it also does little to uncover the mechanisms involved in the amplitude of cycles. An alternative pursued in this section looks for measures of financial stringency, and then examines their effect on the strength of the recovery. In the historical context, measures of financial stringency are associated with more severe recessions (Bordo and Haubrich 2010), and it thus makes sense to look at their effect on the strength of recoveries. 
The first approach makes a distinction between crises based on their severity, as measured by Reinhart and Rogoff (2009). Replacing the crisis dummy in the interaction term with the Reinhart and Rogoff index of crisis severity (which essentially adds up the number of different crises occuring during particular years, which we sum over contractions), we attempt to account for the effect of crisis severity. The results looking out either four quarters from the trough or the duration of the contraction into the expansion were quite similar, so in Table 7 we report only the results for duration. Again the results are somehwat mixed. The financial crisis dummy is usually positve, but insignificant. The interaction term is significant in all four cases, positive except for the post-World War II period. Thus, for most of the sample, a more severe crisis means a stronger recovery.

Another approach preserves the interaction between the simple dummy for financial crises but adds controls for financial conditions during the recovery. To capture both the market-based and the intermediary-based aspects of finance, we include stock prices and bank loans. It is perhaps more common to measure financial conditions via some sort of credit spread, and in our earlier work we followed that tradition and looked at the spread between Baa and safe bonds, or between different grades of railroad bonds for the 19th century. Credit spreads will play an important role in the results of the next section, but here we look more on the quantity side. While certainly the price of credit should matter, some authors (Owens and Schreft, 1995) define a "credit crunch" as nonprice rationing of credit, and thus observable mostly from the quantity side. Schularick and Taylor (2012) use (annual) bank lending as a measure of credit conditions. The stock price index for 1875-1917 is the Cowles commission index, releveled to match the Standard and Poor index which begins in 1917. For bank lending, we construct a new quarterly series from 1882 to 2010 for all commercial banks, detailed in the appendix.

Table 8 reports the results of regressing the expansion strength against contraction depth, the change in real loans over the expansion and the change in the stock index over the expansion. It is meant to uncover whether financing problems held back the recovery. Because adding dependent variables reduces the degrees of freedom, we only report results for the entire sample and for a subsample that excludes the 1929 cycle. The results are somewhat mixed, but the interaction term is postive in the entire sample, both at four quarters and duration, and positive, statistically significant and quantitatively large in three of the four cases considered. Again it appears that if there is a difference between cycles with and without a crisis, the rebound from a financial crisis is particularly strong if the recession was deep.

Looking at the controls, however, shows that financing matters for the recovery, though the results do depend on the horizon, particularly for bank lending. Loans are quantitatively and statistically significant except when 1929 is dropped from the four-quarter specification. Higher bank lending is associated with a stronger 
recovery. The effect on the stock index is more consistent across horizons. There is a positive relationship between changes in the stock index and the strength of recovery, both with and without the Great Depression. Of course, particularly with the stock market, causality is hard to determine, and the results may only be telling us that strong recoveries have bull markets.

\section{The Effect of Housing}

Housing deserves separate attention, if only because it played such a prominent role in the 2007-2008 crisis. In fact, housing has been important in many cycles (Leamer, 2007) and a stylized fact noticed even by Burns and Mitchell is that household investment (which is predominantly housing) leads the business cycle (Fisher, 2007). A standard story for the transmission of monetary policy was that the Federal Reserve would raise rates, which in the days of Regulation Q would lead to disintermediation, cutting off funds needed for construction (Jaffee and Rosen, 1979). Home builders famously sent Paul Volcker hundreds of twoby-fours to protest his raising of rates (Greider, 1987, p. 462). Other work has suggested that a shock to the housing market can account for much of the output decline in the recent recession (Henly and Wolman, 2011). More recently, chairman Bernanke (2011) has remarked that

Notably, the housing sector has been a significant driver of recovery from most recessions in the United States since World War II, but this time-with an overhang of distressed and foreclosed properties, tight credit conditions for builders and potential homebuyers, and ongoing concerns by both potential borrowers and lenders about continued house price declines-the rate of new home construction has remained at less than one-third of its pre-crisis level.

The obvious question is to what extent the problems in the housing market can account for the slow recovery so far. Clearly, questions of precedence, causality and influence are difficult to sort out. Our approach is to ask a counter-factual: What would the current recovery look like if it followed the historical pattern based on the depth of the contraction? Since the recovery in fact is much slower than predicted by just the recession depth, that is, the bounceback is weaker than expected, we see if the effects of the financial crisis or problems in the housing market can account for the difference.

In essence, the first step is to look for outliers in the relationship between recession depth and recovery. If we can identify which recoveries look different, can we start to understand why? We do this in a three-step process. First, as mentioned already, we compare actual with fitted values in a regression of RGDP growth in the recovery against contraction depth, again also measured by the drop in RGDP. We then add a measure of financial distress, the risk spread used in Bordo and Haubrich (2010), Moody's Seasoned Baa less Long-term Treasury Composite, and again compare fitted with actual values. Finally, we add a third 
term, Residential Investment, as our measure of the housing market, comparing actual to fitted values. Using the measures of financial distress and the housing market unfortunately restricts the data to the post-World War I era, though unlike Leamer, we are able to consider the interwar years.

Figure 5 graphically reports the results. (Table 9 reports the regressions.) The first panel compares actual change in real GDP for the recovery (as before, length of the contraction after the trough) with the fitted value from the regression against contraction depth. The most recent three cycles stand out as having particularly weak recoveries given the size of the recessions. Their bounce back is abnormally slow.

The second panel shows how much of the shortfall we attribute to problems in the financial sector. This might be expected to be large, as the 1990 cycle is famous for its financial "headwinds," and the problems of the current crisis need no further recapitulation. Does financial stringency explain the slow recovery? To the measures of loan growth and stock appreciation from the previous section we add the interest rate risk spread. This does improve the fit overall, though for the current crisis the fit worsens. Adding these financial variables also reverses the trend of last three recessions, which no longer look weaker than predicted. So, as noted before, there is some support in the most recent cycles for financial crises to lead to weaker recoveries.

The third panel shows the effect of adding Residential Investment, an obvious measure of the housing market, and a key component of Leamer's (2007) contention that "Housing is the business cycle." This panel shows the actual and fitted values using contraction depth, loan growth, stock appreciation, risk spread, and residential investment. Residential investment is not a large component of national expenditure, but it is closely linked to the purchases of consumer durables and other housing-sensitive sectors, which together give it a bigger impact. The improvement is particularly noticeable for the current recovery. This was also the case in the last five recessions, which show noticeable improvement in fit-a Wald test rejects excluding the extra variables at well above the one percent level. Nevertheless, the orders of magnitude are strikingly greater in the current recovery.

In the absence of a model, of course, this finding points to the need for further analysis, to determine if weakness in housing was directly to blame for the weak recovery, or if it merely reflected or transmitted other problems, such as weakness in the intermediary sector. Nonetheless, the role of housing does stand out as a marker for weakness in the current recovery.

\section{Prospects for the Current Recovery}

Recessions that accompany a financial crisis tend to be long and severe (Bordo and Haubrich, 2010, Reinhart and Rogoff, 2009). What that portends for economic growth once a recovery has started is less certain, however. On the one hand, there is the feeling that "growth is sometimes quite modest in the after- 
math as the financial system resets." (Reinhart and Rogoff, p. 235). On the other hand, there is the stylized fact behind Friedman's plucking model, that "A large contraction in output tends to be followed on the average by a large business expansion," (Friedman, 1969, p. 273). One popular measure, the time required to return output to the pre-crisis level, confounds the depth of the recession with the strength of recovery. For many purposes, it is important to separate the notions of contraction depth and recovery strength.

Where does that leave the current recovery? It remains an outlier, as one of the few cases where output did not return to the level of the previous peak after the duration of the recession. In this it resembled two very different recessions, the Great Depression and 1990. Significantly, both of those combined financial problems and (real) housing price declines, albeit of strikingly different magnitudes. The unanswered question, of course, relates to causality-tracing out the exact shocks, and their transmission, remains key. Must housing recover for the recovery to take off, or will the economy pull the industry along? These are questions for another day.

Also of great importance is the question of whether additional monetary stimulus could speed up the current recovery. Since the end of 2009, short-term interest rates have been close to zero. The Federal Reserve has gone through two rounds of quantitative easing and a maturity extension program designed to lower longterm interest rates and stimulate investment expenditure. Yet the housing sector has not recovered, and residential investment has remained flat. This raises the question of whether further quantitative easing could make the pace of recovery more consistent with the depth of the recession. It is possible that forces other than looser monetary policy may be needed to instill recovery in the housing sector. One possibility is that house prices still need to fall further to clear the market. Then builders would be eager to borrow, knowing that prices will no longer fall, and lenders will be more eager to lend knowing that the value of their collateral has stabilized.

\section{References}

Balke, Nathan S., and Robert J. Gordon, (1986), Appendix B: Historical Data, The American Business cycle: continuity and Change NBER Studies in Business Cycles, University of Chicago Press, Chicago.

Barro, Robert J., and Tao Jin, (2011), "On the Size Distribution of Macroeconomic Disasters," Econometrica, vol. 79.5, pp. 1567-1589.

Beauchemin, Kenneth R., (2010), "Not Your Father's Recovery?" FRB Cleveland Economic Commentary, September 9,.

Bernanke, Ben. S. "The Near- and Longer-Term Prospects for the U.S. Economy" At the Federal Reserve Bank of Kansas City Economic Symposium, Jackson Hole, Wyoming August 26, 2011.

Bordo, Michael D., and John S. Landon-Lane (2010) "The Global Financial Crisis of 2007-2008: Is It Unprecedented?" NBER Working Paper 16589, December 
2010.

Burns, Arthur F., and Wesley C. Mitchell. (1946). Measuring Business Cycles. Studies in Business Cycles, no. 2. New York: NBER.

Cerra, Valerie, and Sweta Chaman Saxena, (2008) "Growth Dynamics: the myth of recovery," American Economic Review, vol. 98.1, pp. 439-457.

Cole, Harold L. and Lee. E Ohanian, (2004) "New Deal Policies and the Persistence of the Great Depression: a general equilibrium analysis," Journal of Political Economy, vol. 112 (4) pp. 779-816.

Eggertsson, Gauti B. (2008) "Great Expectations and the End of the Depression," American Economic Review, 90(4).

Farlow, Stanley J., (1993)Partial Differential Equations for Scientists and Engineers, Dover Publications, Inc., New York.

Fels, Rendig, (1959) American Business Cycles, 1865-1897,University of North Carolina Press, Chapel Hill.

Fisher, Jonas D. M., (2007) "Why Does Household Investment Lead Business Investment over the Business Cycle?" Journal of Political Economy, vol. 115, no. 1, pp. 141-169.

Friedman, Milton (1969) "The Monetary Studies of the National Bureau," Chapter 12 in The Optimum Quantity of Money and Other Essays, Aldine Publishing Company, Chicago (Originally from The National Bureau Enters its 45th year, annual report, 1964).

Friedman, Milton , (1988), "The 'Plucking Model' of Business Fluctuations Revisited," Hoover Institution Working Paper in Economics, E-88-48.

Gali, Jordi, Frank Smets, and Rafael Wouters, (2012) "Slow Recoveries: A Structural Interpretation," NBER Working Paper 18085.

Gordon, Robert J., and Robert Krenn, (2010) "The End of the Great Depression 1939-41: policy contributions and fiscal multipliers," NBER Working Paper 16380.

Greider, William (1987) Secrets of the Temple: How the Federal Reserve runs the country, Simon and Schuster, New York.

Gourio, Francois, (2008) "Disaster and Recoveries," American Economic Review, Papers and Proceedings, vol. 98.2, pp. 68-73.

Hall, Robert E., (2011) "The Long Slump" American Economic Review, vol. 101 no. 2, pp.431-469.

Hall, Thomas E. and J. David Ferguson. (1998) The Great Depression: an international disaster of perverse economic policies. Univeristy of Michagan Press, Ann Arbor.

Harding, Don, and Adrian Pagan, "Dissecting the Cycle: a methodological investigation," Journal of Monetary Economics, vol. 29, no. 2, March 2002, pp. 365-381.

Henly, Samuel E. and Alexander L. Wolman, (2011)"Housing and the Great Recession: a VAR accounting exercise," Economic Quarterly, FRB Richmond, 97.1 , pp. $45-66$. 
Hetzel, Robert L.(2008) The Monetary Policy of the Federal Reserve: A History. Cambridge University Press, Cambridge.

Jaffe, Dwight M., and Kenneth T. Rosen, (1979) "Mortgage Credit Availibiility and Residential Construction," Brookings Papers on Economic Activity, pp. 33376 .

Leamer,Edward E., 2007. "Housing is the business cycle," Proceedings, Federal Reserve Bank of Kansas City, pages 149-233

Lopez-Salido, David and Edward Nelson, "Postwar Financial Crises and Economic Recoveries in the United States," Working paper, May 21, 2010.

Macroeconomic Advisors, "The Shape of Things to Come," MA Macro Focus, April 27, 2009, vol. 4, no. 6.

Meltzer, Allan H. (2003) A History of the Federal Reserve, Volume 1: 1913-1951 University of Chicago Press, Chicago.

Meltzer, Allan H. (2010) A History of the Federal Reserve, Volume 2 book 1: 1951-1969 University of Chicago Press, Chicago.

Odell, Kerry, and Marc Weidenmier, (2004). "Real Shock, Monetary Aftershock: The 1906 San Francisco Earthquake and the Panic of 1907," Journal of Economic History, Vol. 64, 1002-1027.

Owens, Raymond E.and Stacey L. Schreft (1995) "Identifying Credit Crunches," Contemporary Economic Policy, Volume 13, Issue 2, pages 63-76.

Papell, David H., and Ruxandra Prodan (2011), "The Statistical Behavior of GDP after Financial Crises and Severe Recessions,.

Reinhart, Carmen S., and Kenneth S. Rogoff, (2009) This Time is Different: Eight centuries of financial folly, Princeton University Press, Princeton.

Romer, Christina D.(1992) "What Ended the Great Depression?" The Journal of Economic History, vol. 52 no. 4 pp. 757-784.

Romer, Christina D. (1994) "Remeasuring Business Cycles" The Journal of Economic History,, vol. 54.3 pp. 573-609.

Romer, Christina D and David H. Romer. (1994). "Monetary Policy Matters." Journal of Monetary Economics 34 (August): 75-88.

Roubini, Nouriel, "A Phantom Recovery?" Project Syndicate, 14 August 2009.

Schularick, Moritz, and Alan M. Taylor, (2012) "Credit Booms Gone Bust: monetary policy, leverage cycles, and financial crises, 1870-2008" American Economic Review, 102(2) pp. 1029-1061.

Stock, James H., and Mark W. Watson,(2012) "Disentangling the Channels of the 2007-2009 Recession," NBER Working Paper 18094.

White, Eugene N. "Lessons from the Great American Real Estate Boom and Bust of the 1920s," NBER Working Paper 15573 December 2009.

Wynne, Mark A. and Nathan S. Balke,(1993) "Recessions and Recoveries," Economic Review, Federal Reserve Bank of Dallas, Q1, 1993, pp. 1-17.

Wynne, Mark A. and Nathan S. Balke, (1992)"Are Deep Recessions Followed by Strong Recoveries?" Economics Letters, vol. 39, pp. 183-189. 
Zarnowitz, Victor (1992), Business cycles: Theory, history, indicators, and forecasting University of Chicago Press, Chicago. 


\section{DATA APPENDIX}

Construction of the quarterly bank loan numbers. We started with the Annual numbers for all commercial banks, Millenial statistics, table Cj253 "Commercial Banks-number and assets." Total Loans. After 1914Q4 these are made quarterly by interpolation using RATS disaggregate (linear, ar1) procedure using Total Loans for all member banks, from the Fed's Banking and Monetary Statistics, 1914-1941 No. 18, All Member banks-Principal assets, "Loans" p. 72-74. The data were pushed forward to 1955 Q4 using the data from Banking and Monetary Statistics 1941-1970 table 2.1 All Member Banks A. Total assets and number of bank loans. There were several missing quarters, which we interpolated using No. 48, Weekly Reporting Banks in 101 Leading Cities-Principal Assets and Liabilities, weekly and monthly.

To go back further, we again began with the Millenial statistics, and interpolated again, this time using national and state bank data. The national bank data came from the NBER series, adding up NBER 14016, Loans and Discounts, national banks, country districts, NBER 14018, Loans and discounts, national banks, Reserve cities other than central, and NBER 14019, Loans and Discounts, National Banks, Central Reserve cities. Some judgment was used to apportion the data into quarters.

Annual State bank data comes from Millenial Statistics, Cj151, State banks, Loans and discounts. It was made quarterly by linear interpolation. The state and national bank numbers were added together and used to interpolate the Millenial statistics annual number. This let us interpolate from 1896 to 1913. Then we attached the series for state and national banks, discounting by the ratio for that series to the Millenial series in 1914. This gave us a series from 1882 to 1955. Figure A1 shows the series.

\section{The Simple Analytics of the (literal) Plucking Model}

Friedman provides a simple intuitive description of the "plucking Model" of business cycles, and one of us (Bordo) had the privledge of hearing him describe it in class. This note describes some simple consequences for business cycle facts obtained by taking the model literally.

The standard way to model the motion of a vibrating string uses what is known as the one-dimensional wave equation, a partial differential equation (PDE) of the Hyperbolic type (Farlow, 1993, Lesson 16). This equation is

$$
u_{t t}=a^{2} u_{x x}
$$

where $\mathrm{u}(\mathrm{x}, \mathrm{t})$ denotes the position of the string as a function of horizontal position and time.

The equation also has boundary conditions. For the plucking model, these naturally take the form of fixing the starting location $(x=0)$, the ending location 
$(x=L)$, and the pluck point $(x=P)$, yielding

$$
\begin{gathered}
u(0, t)=y_{0} \\
u(L, t)=y_{L} \\
u(P, 0)=y_{P} .
\end{gathered}
$$

Here $\mathrm{L}$ is the length of the business cycle, and pluck point should be expressed as a fraction of $\mathrm{L}$, so that

$$
p=\frac{P}{L}
$$

This of course is not fully generally-the end point need not be fully fixed, as it may have an elastic connection, and it takes the length of the cycle as already known, so that once the length of the contraction (time from the start to $\mathrm{P}$ ) is known, the length of the recovery (from $\mathrm{P}$ to $\mathrm{L}$ ) is also known. Still, the simple formulation provides a way to think about various slope relations between expansions and contractions in a structured manner.

Our interpretation given Friedman's writings and teachings is that the initial, static, shape of the string describes the time series of aggregate income. This makes the analytics very simple, because the static equilibrium (before the string is released) is easy to calculate. Since the string is not moving $u_{t t}=0$ and consequently $u_{x x}=0$, and the string position is piecewise linear, subject to the boundary conditions. Assuming a downward pluck (since we are talking about a contraction) we set:

$$
\begin{aligned}
& y_{0}=0 \\
& y_{L} \geq y_{0} \\
& y_{P} \leq 0 .
\end{aligned}
$$

This yields simple expressions for the slope of the business cycle segments. The contraction slope is

$$
S^{C}=\frac{Y_{P}-Y_{0}}{p L}
$$

And the expansion slope is

$$
S^{E}=\frac{Y_{L}-Y_{P}}{L-P} .
$$


Then

$$
\frac{\partial S^{C}}{\partial p}=\frac{\left(Y_{0}-Y_{P}\right)}{p L^{2}}>0 .
$$

$$
\frac{\partial S^{C}}{\partial Y_{P}}=\frac{1}{p L}>0
$$

As the contraction becomes longer (as a fraction of the cycle) the slope becomes flatter (less negative). As the depth of the contraction decreases, the contraction becomes more shallow.

$$
\begin{gathered}
\frac{\partial S^{E}}{\partial p}=\frac{L\left(Y_{L}-Y_{P}\right)}{(1-p)^{2} L^{2}}>0 . \\
\frac{\partial S^{E}}{\partial Y_{P}}=\frac{-1}{(1-p) L}<0 .
\end{gathered}
$$

As the contraction gets longer, the slope of the recovery gets steeper. As the contraction gets deeper, the slope of the recovery gets steeper. This corresponds to Friedman's analysis. 
Table 1: Output Change in Business Cycles, 1880-2011

\begin{tabular}{|c|c|c|c|c|c|c|}
\hline & Steepness & & $\begin{array}{l}\text { RGDP } \\
\text { Change }\end{array}$ & & $\begin{array}{l}\text { Percent } \\
\text { change }\end{array}$ & \\
\hline PEAK & Contraction & Recovery & Cont & Rec & Cont & Rec \\
\hline March $1882(\mathrm{I})$ & $0.20 \%$ & $0.40 \%$ & 2.59 & 5.14 & $3.15 \%$ & $6.25 \%$ \\
\hline March 1887 (II) & $-1.12 \%$ & $0.77 \%$ & -3.36 & 2.32 & $-3.75 \%$ & $2.70 \%$ \\
\hline July 1890 (III) & $-0.34 \%$ & $4.42 \%$ & -1.03 & 13.27 & $-1.05 \%$ & $13.72 \%$ \\
\hline January 1893 (I) & $-2.48 \%$ & $3.44 \%$ & -12.38 & 17.21 & $-11.09 \%$ & $17.33 \%$ \\
\hline December 1895 (IV) & $0.28 \%$ & $0.81 \%$ & 1.67 & 4.86 & $1.41 \%$ & $4.04 \%$ \\
\hline June 1899 (III) & $0.58 \%$ & $3.08 \%$ & 2.92 & 15.39 & $2.10 \%$ & $10.88 \%$ \\
\hline September 1902 (IV) & $0.48 \%$ & $4.48 \%$ & 3.34 & 31.37 & $2.09 \%$ & $19.23 \%$ \\
\hline May 1907 (II) & $-6.03 \%$ & $5.89 \%$ & -24.13 & 23.54 & $-11.82 \%$ & $13.08 \%$ \\
\hline January 1910(I) & $0.52 \%$ & $0.75 \%$ & 7.71 & 11.55 & $3.61 \%$ & $5.22 \%$ \\
\hline January 1913 (I) & $-2.77 \%$ & $3.47 \%$ & -19.38 & 24.28 & $-8.33 \%$ & $11.39 \%$ \\
\hline August 1918 (III) & $-11.93 \%$ & $-21.83 \%$ & -23.86 & -43.67 & $-8.34 \%$ & $-16.66 \%$ \\
\hline January 1920 (I) & $-1.28 \%$ & $5.55 \%$ & -7.66 & 33.28 & $-3.42 \%$ & $15.39 \%$ \\
\hline May 1923 (II) & $2.80 \%$ & $2.46 \%$ & 13.99 & 12.32 & $5.43 \%$ & $4.54 \%$ \\
\hline October 1926 (III) & $-0.76 \%$ & $5.37 \%$ & -3.78 & 26.84 & $-1.26 \%$ & $9.08 \%$ \\
\hline August 1929 (III) & $-7.14 \%$ & $6.26 \%$ & -99.95 & 87.64 & $-31.60 \%$ & $40.51 \%$ \\
\hline May 1937 (II) & $-5.49 \%$ & $6.88 \%$ & -21.96 & 27.52 & $-6.96 \%$ & $9.37 \%$ \\
\hline February 1945 (I) & $-40.98 \%$ & $-16.66 \%$ & -122.94 & -49.97 & $-19.25 \%$ & $-9.69 \%$ \\
\hline November 1948 (IV) & $0.96 \%$ & $10.00 \%$ & 3.86 & 40.02 & $0.81 \%$ & $8.36 \%$ \\
\hline July 1953 (II) & $-3.99 \%$ & $12.11 \%$ & -15.96 & 48.43 & $-2.53 \%$ & $7.88 \%$ \\
\hline August 1957 (III) & $-7.32 \%$ & $15.44 \%$ & -21.95 & 46.31 & $-3.15 \%$ & $6.86 \%$ \\
\hline April 1960 (II) & $-1.35 \%$ & $14.07 \%$ & -4.04 & 42.22 & $-0.54 \%$ & $5.62 \%$ \\
\hline December 1969 (IV) & $-0.45 \%$ & $12.63 \%$ & -1.80 & 50.50 & $-0.16 \%$ & $4.45 \%$ \\
\hline November 1973 (IV) & $-8.40 \%$ & $17.78 \%$ & -42.00 & 88.90 & $-3.18 \%$ & $6.96 \%$ \\
\hline January 1980 (I) & $-17.55 \%$ & $30.50 \%$ & -35.10 & 61.00 & $-2.23 \%$ & $3.96 \%$ \\
\hline July 1981 (III) & $-8.48 \%$ & $30.68 \%$ & -42.40 & 153.42 & $-2.64 \%$ & $9.81 \%$ \\
\hline July 1990 (III) & $-14.55 \%$ & $11.63 \%$ & -29.09 & 23.25 & $-1.36 \%$ & $1.10 \%$ \\
\hline March 2001 (I) & $7.31 \%$ & $19.24 \%$ & 21.92 & 57.71 & $0.73 \%$ & $1.90 \%$ \\
\hline December 2007 (IV) & $-30.41 \%$ & $25.53 \%$ & -182.49 & 153.21 & $-5.14 \%$ & $4.55 \%$ \\
\hline
\end{tabular}

Steepness is change divided by duration; Recoveries are measured by the duration of contraction after the trough; RGDP in 1972 dollars.

Source: Authors' calculations based on Bordo and Haubrich (2010), Gordon and Krenn (2010) Balke and Gordon (1986), and NIPA accounts. 
Table 2 Descriptive Evidence on U.S. Recoveries 1880-2011

A. Pre-Federal Reserve 1880-1920

Recessions with recoveries that are at least as rapid as the downturn

\begin{tabular}{|c|l|l|l|l|l|l|}
\hline Trough & Recovery & $\begin{array}{l}\text { Major } \\
\text { Recession }\end{array}$ & $\begin{array}{l}\text { Banking } \\
\text { Crisis }\end{array}$ & $\begin{array}{l}\text { Credit } \\
\text { Crunch }\end{array}$ & $\begin{array}{l}\text { Housing } \\
\text { Bust }\end{array}$ & $\begin{array}{l}\text { Stock } \\
\text { Crash }\end{array}$ \\
\hline $1885(\mathrm{II})$ & $1885(\mathrm{II})-1887(\mathrm{II})$ & No & Sept. 1884 & Yes & No & Feb. 1884 \\
\hline $1888(\mathrm{I})$ & $1888(\mathrm{I})-1890(\mathrm{III})$ & No & No & No & No & No \\
\hline $1891(\mathrm{II})$ & $1891(\mathrm{II})-1893(\mathrm{I})$ & No & Nov. 1890 & No & No & Nov. 1890 \\
\hline $1891(\mathrm{II})$ & $1894(\mathrm{II})-1895(\mathrm{IV})$ & Yes & May 1893 & Yes & $?$ & May 1893 \\
\hline $1894(\mathrm{II})$ & $1894(\mathrm{II})-1895(\mathrm{IV})$ & No & No & No & No & No \\
\hline $1897(\mathrm{II})$ & $1897(\mathrm{II})-1899(\mathrm{III})$ & No & No & No & No & No \\
\hline $1900(\mathrm{IV})$ & $1900(\mathrm{IV})-1902(\mathrm{IV})$ & No & No & No & No & Oct. 1903 \\
\hline $1908(\mathrm{II})$ & $1908(\mathrm{II})-1910(\mathrm{I})$ & Yes & Oct. 1907 & Yes & $?$ & Oct. 1907 \\
\hline $1911(\mathrm{IV})$ & $1911(\mathrm{IV})-1914(\mathrm{IV})$ & No & No & No & No & No \\
\hline $1914(\mathrm{IV})$ & $1914(\mathrm{IV})-1918(\mathrm{III})$ & No & Yes & No & $?$ & Fall 1917 \\
\hline
\end{tabular}

Recessions with recoveries that were slower than the downturn

\begin{tabular}{|l|l|l|l|l|l|l|l}
\hline Trough & Recovery & $\begin{array}{l}\text { Major } \\
\text { Recession }\end{array}$ & $\begin{array}{l}\text { Banking } \\
\text { Crisis }\end{array}$ & $\begin{array}{l}\text { Credit } \\
\text { Crunch }\end{array}$ & $\begin{array}{l}\text { Housing } \\
\text { Bust }\end{array}$ & $\begin{array}{l}\text { Stock } \\
\text { Crash }\end{array}$ & \\
\hline 1919(I) & $1919(\mathrm{I})-1920(\mathrm{I})$ & No & No & No & No & No & \\
\hline
\end{tabular}

Source: Bordo and Haubrich (2010), Friedman and Schwartz (1963), Shiller (2009)

?-Shiller (2009) shows a drop in real house prices.

B. Interwar 1920-1945

Recessions with recoveries that are as least as rapid as the downturn

\begin{tabular}{|l|l|l|l|l|l|l|}
\hline Trough & Recovery & $\begin{array}{l}\text { Major } \\
\text { Recession }\end{array}$ & $\begin{array}{l}\text { Banking } \\
\text { Crisis }\end{array}$ & $\begin{array}{l}\text { Credit } \\
\text { Crunch }\end{array}$ & $\begin{array}{l}\text { Housing } \\
\text { Bust }\end{array}$ & $\begin{array}{l}\text { Stock } \\
\text { Crash }\end{array}$ \\
\hline $1921(\mathrm{III})$ & 1921 (III)-1923(II) & Yes & No & No & $?$ & Fall 1920 \\
\hline $1924(\mathrm{III})$ & $1924(\mathrm{III})-1926(\mathrm{III})$ & No & No & No & No & No \\
\hline $1927(\mathrm{II})$ & $1927(\mathrm{IV})-1929(\mathrm{III})$ & No & No & No & Yes & No \\
\hline $1938(\mathrm{II})$ & $1938(\mathrm{II})-1945(\mathrm{I})$ & Yes & No & Yes & No & $\begin{array}{l}\text { Feb 1937, } \\
\text { May 1940 }\end{array}$ \\
\hline
\end{tabular}

Recessions with Recoveries that were slower than the downturn

\begin{tabular}{|l|l|l|l|l|l|l|}
\hline Trough & Recovery & $\begin{array}{l}\text { Major } \\
\text { Recession }\end{array}$ & $\begin{array}{l}\text { Banking } \\
\text { Crisis }\end{array}$ & $\begin{array}{l}\text { Credit } \\
\text { Crunch }\end{array}$ & $\begin{array}{l}\text { Housing } \\
\text { Bust }\end{array}$ & $\begin{array}{l}\text { Stock } \\
\text { Crash }\end{array}$ \\
\hline 1933(I) & $1933(\mathrm{I})-1937(\mathrm{II})$ & Yes & $1930,1931,1933$ & Yes & Yes & Oct. 1929 \\
\hline
\end{tabular}


C. Postwar 1948-2011

Recession with recoveries that are at least as rapid as the downturn

\begin{tabular}{|c|l|l|l|l|l|l|}
\hline Trough & Recovery & $\begin{array}{l}\text { Major } \\
\text { Recession }\end{array}$ & $\begin{array}{l}\text { Banking } \\
\text { Crisis }\end{array}$ & $\begin{array}{l}\text { Credit } \\
\text { Crunch }\end{array}$ & $\begin{array}{l}\text { Housing } \\
\text { Bust }\end{array}$ & $\begin{array}{l}\text { Stock } \\
\text { Crash }\end{array}$ \\
\hline $1945(\mathrm{IV})$ & $1945(\mathrm{IV})-1948(\mathrm{IV})$ & No & No & No & No & Sept. 1946 \\
\hline $1949(\mathrm{IV})$ & $1949(\mathrm{IV})-1953(\mathrm{II})$ & No & No & No & No & No \\
\hline $1954(\mathrm{II})$ & $1954(\mathrm{II})-1957(\mathrm{III})$ & No & No & Yes & No & No \\
\hline $1958(\mathrm{II})$ & $1958(\mathrm{II})-1960(\mathrm{II})$ & No & No & Yes & No & No \\
\hline $1961(\mathrm{II})$ & $1961(\mathrm{II})-1969(\mathrm{IV})$ & No & No & Yes & No & Spring 1966 \\
\hline $1970(\mathrm{I})$ & $1970(\mathrm{I})-1973(\mathrm{IV})$ & No & No & Yes & No & May 1970 \\
\hline $1975(\mathrm{I})$ & $1975(\mathrm{I})-1980(\mathrm{I})$ & Yes & Yes & Yes & $?$ & Nov. 1973 \\
\hline $1980(\mathrm{III})$ & $1980(\mathrm{III})-1981(\mathrm{III})$ & No & No & Yes & No & No \\
\hline $1982(\mathrm{IV})$ & $1982(\mathrm{IV})-1990(\mathrm{III})$ & Yes & Yes* & Yes & No & Aug. 1990 \\
\hline $2001(\mathrm{IV})$ & $2001(\mathrm{IV})-2007(\mathrm{IV})$ & No & No & No & No & Spring 2001 \\
\hline
\end{tabular}

Recession with Recoveries that were slower than the downturn

\begin{tabular}{|c|l|l|l|l|l|l|}
\hline Trough & Recovery & $\begin{array}{l}\text { Major } \\
\text { Recession }\end{array}$ & $\begin{array}{l}\text { Banking } \\
\text { Crisis }\end{array}$ & $\begin{array}{l}\text { Credit } \\
\text { Crunch }\end{array}$ & $\begin{array}{l}\text { Housing } \\
\text { Bust }\end{array}$ & $\begin{array}{l}\text { Stock } \\
\text { Crash }\end{array}$ \\
\hline 1991(I) & $1991(\mathrm{I})-2001(\mathrm{I})$ & No & Yes* & Yes & $?$ & No \\
\hline 2009(II) & $2009(\mathrm{II})-?$ & Yes & Sept. 2008 & Yes & Yes & Oct. 2008 \\
\hline
\end{tabular}

Source: Bordo and Haubrich (2010), Friedman and Schwartz (1963), Shiller (2009)

?-Shiller (2009) shows a drop in real house prices.

-*Lopez-Salido and Nelson (2010) identify a banking crisis. 
Table 3: Regressions of 4 quarter expansion growth on contraction amplitude

\begin{tabular}{|c|c|c|c|c|}
\hline Variable & All & No 29 & Post-Fed & Post WW2 \\
\hline Constant & $6.125^{* * *}$ & $6.180^{* * *}$ & $4.807^{* * *}$ & $5.589^{* * *}$ \\
\hline$C_{A m n}$ & 0.111 & 0.076 & 0.079 & 0.599 \\
\hline & $(0.089)$ & $(0.280)$ & $(0.128)$ & $(0.328)$ \\
\hline$R^{2}$ & 0.01 & 0.003 & 0.01 & 0.01 \\
\hline $\mathrm{N}$ & 27 & 26 & 17 & 11 \\
\hline Constant & $\begin{array}{c}6.434^{* * *} \\
(1.044)\end{array}$ & $\begin{array}{c}6.434^{* * *} \\
(1.044)\end{array}$ & $\begin{array}{c}5.658^{* * *} \\
(1.301)\end{array}$ & $\begin{array}{c}5.539^{* * *} \\
(1.242)\end{array}$ \\
\hline FinDum & $\begin{array}{c}-0.5864 \\
(1.293)\end{array}$ & $\begin{array}{l}-2.360^{*} \\
(1.381)\end{array}$ & $\begin{array}{l}-1.254 \\
(1.536)\end{array}$ & $\begin{array}{l}-0.404 \\
(1.917)\end{array}$ \\
\hline$C_{A m p}$ & $\begin{array}{l}-0.565 \\
(0.556)\end{array}$ & $\begin{array}{c}-0.565 \\
(0.556)\end{array}$ & $\begin{array}{l}-0.510 \\
(0.705)\end{array}$ & $\begin{array}{c}0.756 \\
(0.541)\end{array}$ \\
\hline FinDum $* C_{A m p}$ & $\begin{array}{c}0.796 \\
(0.593)\end{array}$ & $\begin{array}{l}1.219^{* *} \\
(0.559)\end{array}$ & $\begin{array}{c}0.692 \\
(0.704)\end{array}$ & $\begin{array}{l}-0.816 \\
(0.740)\end{array}$ \\
\hline$R^{2}$ & 0.16 & 0.20 & 0.12 & 0.20 \\
\hline Chow Test $\chi^{2}(2)$ & 2.18 & $8.13^{* *}$ & 1.574 & 2.605 \\
\hline Sig level & 0.34 & 0.02 & 0.46 & 0.27 \\
\hline
\end{tabular}


Table 4: Regressions of Duration expansion growth on contraction amplitude

\begin{tabular}{|c|c|c|c|c|}
\hline Variable & All & No 29 & Post-Fed & Post WW2 \\
\hline Constant & $\begin{array}{c}5.982^{* * *} \\
(1.312)\end{array}$ & $\begin{array}{c}7.059 * * * \\
(0.996)\end{array}$ & $\begin{array}{c}3.765^{* * *} \\
(1.281)\end{array}$ & $\begin{array}{c}5.042^{* * *} \\
(1.244)\end{array}$ \\
\hline$C_{A m p}$ & $\begin{array}{c}0.740^{* * *} \\
(0.273)\end{array}$ & $\begin{array}{c}0.060 \\
(0.324)\end{array}$ & $\begin{array}{c}0.911^{* * *} \\
(0.250)\end{array}$ & $\begin{array}{c}0.310 \\
(0.357)\end{array}$ \\
\hline$R^{2}$ & 0.32 & 0.001 & 0.43 & 0.04 \\
\hline $\mathrm{N}$ & 27 & 26 & 17 & 11 \\
\hline Constant & $\begin{array}{c}7.229 * * * \\
(1.875)\end{array}$ & $\begin{array}{c}7.229^{* * * *} \\
(1.090)\end{array}$ & $\begin{array}{c}6.281^{* * *} \\
(1.026)\end{array}$ & $\begin{array}{c}5.159^{* * * *} \\
(1.251)\end{array}$ \\
\hline FinDum & $\begin{array}{c}-3.663^{*} \\
(2.246)\end{array}$ & $\begin{array}{l}-2.251 \\
(1.820)\end{array}$ & $\begin{array}{c}-4.376^{* *} \\
(1.776)\end{array}$ & $\begin{array}{l}-1.168 \\
(2.538)\end{array}$ \\
\hline$C_{A m p}$ & $\begin{array}{l}-0.790 \\
(0.573)\end{array}$ & $\begin{array}{l}-0.790 \\
(0.573)\end{array}$ & $\begin{array}{l}-0.677 \\
(0.738)\end{array}$ & $\begin{array}{c}0.415 \\
(0.488)\end{array}$ \\
\hline FinDum $* C_{A m p}$ & $\begin{array}{c}1.886^{* * *} \\
(0.552)\end{array}$ & $\begin{array}{c}1.549^{* *} \\
(0.603)\end{array}$ & $\begin{array}{c}1.893^{* *} \\
(0.735)\end{array}$ & $\begin{array}{c}0.109 \\
(0.849)\end{array}$ \\
\hline$R^{2}$ & 0.51 & 0.23 & 0.67 & 0.06 \\
\hline Chow Test $\chi^{2}(2)$ & $15.51^{* * *}$ & $7.48^{* *}$ & $11.95^{* * *}$ & 0.303 \\
\hline Sig level & 0.004 & 0.02 & 0.003 & 0.86 \\
\hline
\end{tabular}


Table 5: Regressions of 4 quarter expansion steepness on contraction steepness

\begin{tabular}{lcccc}
\hline Variable & All & No 29 & Post-Fed & Post WW2 \\
\hline Constant & $1.810^{* * *}$ & $1.801^{* * *}$ & $1.744^{* * *}$ & $1.385^{* * *}$ \\
& $(0.232)$ & $(0.227)$ & $(0.320)$ & $(0.303)$ \\
$C_{\text {stp }}$ & -0.259 & -0.324 & -0.602 & 0.140 \\
& $(0.441)$ & $(0.450)$ & $(0.494)$ & $(0.325)$ \\
$R^{2}$ & 0.05 & 0.07 & 0.24 & 0.01 \\
$\mathrm{~N}$ & 27 & 26 & 17 & 11 \\
\hline Constant & $1.833^{* * *}$ & $1.833^{* * *}$ & $1.713^{* * *}$ & $1.430^{* * *}$ \\
& $(0.252)$ & $(0.252)$ & $(0.363)$ & $(0.310)$ \\
FinDum & $-0.906^{* * *}$ & $-0.916^{* * *}$ & $-0.923^{*}$ & $2.096^{* * *}$ \\
& $(0.298)$ & $(0.300)$ & $(0.473)$ & $(0.593)$ \\
$C_{\text {stp }}$ & $-0.776^{* *}$ & $-0.776^{* *}$ & $-0.771^{* *}$ & 0.366 \\
& $(0.346)$ & $(0.346)$ & $(0.390)$ & $(0.453)$ \\
FinDum $* C_{\text {stp }}$ & $1.585^{* * *}$ & $1.617^{* * *}$ & $1.487^{* * *}$ & $-3.787^{* * *}$ \\
& $(0.368)$ & $(0.366)$ & $(0.405)$ & $(0.764)$ \\
$R^{2}$ & 0.42 & 0.41 & 0.39 & 0.30 \\
Chow Test $\chi^{2}(2)$ & $22.77^{* * *}$ & $23.48^{* * *}$ & $13.52^{* * *}$ & 25.61 \\
Sig level & 0.000 & 0.000 & 0.001 & 0.000 \\
& HAC robust standard errors in parentheses \\
& $*, * *, * *$ Significant at $10 \%, 5 \%$ and $1 \%$ level
\end{tabular}


Table 6: Regressions of Duration expansion steepness on contraction steepness

\begin{tabular}{|c|c|c|c|c|}
\hline Variable & All & No 29 & Post-Fed & Post WW2 \\
\hline \multirow[t]{2}{*}{ Constant } & $1.939^{* * *}$ & $1.923^{* * *}$ & $2.151^{* * *}$ & $1.372^{* * *}$ \\
\hline & $(0.312)$ & $(0.302)$ & $(0.444)$ & $(0.280)$ \\
\hline \multirow[t]{2}{*}{$C_{s t p}$} & -0.663 & -0.7832 & -1.349 & 0.287 \\
\hline & $(0.762)$ & $(0.777)$ & $(0.836)$ & $(0.263)$ \\
\hline$R^{2}$ & 0.12 & 0.13 & 0.38 & 0.04 \\
\hline $\mathrm{N}$ & 27 & 26 & 17 & 11 \\
\hline Constant & $\begin{array}{c}1.965^{* * *} \\
(0.361)\end{array}$ & $\begin{array}{c}1.965 * * * \\
(0.361)\end{array}$ & $\begin{array}{c}2.068^{* * *} \\
(0.487)\end{array}$ & $\begin{array}{c}1.467 * * * \\
(0.269)\end{array}$ \\
\hline FinDum & $\begin{array}{c}-1.3741^{* * *} \\
(0.381)\end{array}$ & $\begin{array}{c}-1.371^{* * *} \\
(0.382)\end{array}$ & $\begin{array}{c}-1.513^{* * *} \\
(0.540)\end{array}$ & $\begin{array}{c}2.126^{* * *} \\
(0.717)\end{array}$ \\
\hline$C_{s t p}$ & $\begin{array}{c}-1.475^{* *} \\
(0.627)\end{array}$ & $\begin{array}{c}-1.475^{* *} \\
(0.627)\end{array}$ & $\begin{array}{c}-1.652^{* *} \\
(0.641)\end{array}$ & $\begin{array}{c}0.655^{* *} \\
(0.3050)\end{array}$ \\
\hline FinDum $* C_{s t p}$ & $\begin{array}{c}2.475^{* * *} \\
(0.639)\end{array}$ & $\begin{array}{c}2.468^{* * *} \\
(0.643)\end{array}$ & $\begin{array}{c}2.616^{* * *} \\
(0.649)\end{array}$ & $\begin{array}{c}-4.253^{* * *} \\
(1.037)\end{array}$ \\
\hline$R^{2}$ & 0.48 & 0.47 & 0.54 & 0.56 \\
\hline Chow Test $\chi^{2}(2)$ & $123.45^{* * *}$ & $22.972^{* * *}$ & $17.615^{* * *}$ & 38.90 \\
\hline Sig level & 0.000 & 0.000 & 0.000 & 0.000 \\
\hline
\end{tabular}


Table 7: Regressions of Duration expansion growth on contraction amplitude and RNR crises severity

\begin{tabular}{|c|c|c|c|c|}
\hline Variable & All & No 29 & Post-Fed & Post WW2 \\
\hline Constant & $\begin{array}{c}5.983^{* * *} \\
(1.312)\end{array}$ & $\begin{array}{c}7.059^{* * *} \\
(0.996)\end{array}$ & $\begin{array}{c}3.765^{* * *} \\
(1.281)\end{array}$ & $\begin{array}{c}5.042^{* * *} \\
(1.244)\end{array}$ \\
\hline$C_{A m p}$ & $\begin{array}{c}0.740^{* * *} \\
(0.273)\end{array}$ & $\begin{array}{c}0.060 \\
(0.324)\end{array}$ & $\begin{array}{c}0.911^{* * *} \\
(0.250)\end{array}$ & $\begin{array}{c}0.310 \\
(0.357)\end{array}$ \\
\hline$R^{2}$ & 0.32 & 0.001 & 0.43 & 0.04 \\
\hline $\mathrm{N}$ & 27 & 26 & 17 & 11 \\
\hline Constant & $\begin{array}{c}6.839^{* * *} \\
(1.144)\end{array}$ & $\begin{array}{c}7.207^{* * *} \\
(1.098)\end{array}$ & $\begin{array}{c}6.215^{* * *} \\
(1.036)\end{array}$ & $\begin{array}{c}4.811^{* * *} \\
(1.388)\end{array}$ \\
\hline FinDum & $\begin{array}{l}1.708 \\
(2.703)\end{array}$ & $\begin{array}{l}-0.755 \\
(1.884)\end{array}$ & $\begin{array}{l}0.111 \\
(2.305)\end{array}$ & $\begin{array}{c}0.764 \\
(2.109)\end{array}$ \\
\hline$C_{A m p}$ & $\begin{array}{c}-0.382 \\
(0.462)\end{array}$ & $\begin{array}{l}-0.767 \\
(0.566)\end{array}$ & $\begin{array}{l}-0.640 \\
(0.727)\end{array}$ & $\begin{array}{c}0.761 \\
(0.60605)\end{array}$ \\
\hline$R n R D u m * C_{A m p}$ & $\begin{array}{c}0.103^{* * *} \\
(0.031)\end{array}$ & $\begin{array}{c}0.316^{* * *} \\
(0.122)\end{array}$ & $\begin{array}{c}0.123^{* *} \\
(0.048)\end{array}$ & $\begin{array}{c}-0.227^{* *} \\
(0.124)\end{array}$ \\
\hline$R^{2}$ & 0.55 & 0.23 & 0.66 & 0.14 \\
\hline Chow Test $\chi^{2}(2)$ & $18.23^{* * *}$ & $7.86^{* *}$ & $13.70^{* * *}$ & 4.43 \\
\hline Sig level & 0.000 & 0.020 & 0.001 & 0.109 \\
\hline
\end{tabular}


Table 8: Regressions of expansion on contraction depth, controlling for change in stock price, and bank loans 1887-2007

\begin{tabular}{lcccc}
\hline Variable & All(4Q) & No $29(4 \mathrm{Q})$ & All (Dur) & no 29 (dur) \\
\hline Constant & $2.928^{* * *}$ & $3.013^{* *}$ & 1.992 & $2.607^{* *}$ \\
$C_{A m p}$ & $(1.073)$ & $(0.992)$ & $(1.603)$ & $(1.043)$ \\
& 0.122 & 0.017 & $0.569^{* *}$ & 0.035 \\
Loan & $(0.209)$ & $(0.305)$ & $(0.285)$ & $(0.337)$ \\
& 0.219 & $0.284^{* *}$ & 0.092 & $0.447^{* * *}$ \\
Stock & $(0.153)$ & $(0.128)$ & $(0.137)$ & $(0.011)$ \\
& $0.166^{* *}$ & $0.154^{* *}$ & $0.242^{* *}$ & $0.114^{* *}$ \\
$R^{2}$ & $(0.078)$ & $(0.068)$ & $(0.098)$ & $(0.055)$ \\
$\mathrm{N}$ & 0.17 & 0.17 & 0.44 & 0.26 \\
Constant & 26 & 25 & 26 & 25 \\
FinDum & 3.206 & $3.563^{* * *}$ & $3.723^{* * *}$ & $3.031^{* *}$ \\
& $(1.084)$ & $(1.168)$ & $(1.206)$ & $(1.252)$ \\
$C_{\text {Amp }}$ & -0.400 & -2.908 & $-5.158^{* * *}$ & -1.025 \\
& $(1.112)$ & $(1.793)$ & $(1.746)$ & $(1.762)$ \\
FinDum $* C_{A m p}$ & -0.535 & -0.535 & -0.719 & -0.652 \\
& $(0.567)$ & $(0.557)$ & $(0.588)$ & $(0.573)$ \\
Loan & 0.853 & $1.219^{* *}$ & $1.909^{* * *}$ & $1.243^{* *}$ \\
& $(0.558)$ & $(0.573)$ & $(0.560)$ & $(0.532)$ \\
Stock & $0.307^{* * *}$ & 0.200 & $0.199^{* * *}$ & $0.361^{* * *}$ \\
$R^{2}$ & $(0.093)$ & $(0.131)$ & $(0.071)$ & $(0.110)$ \\
Chow Test $\chi^{2}(2)$ & $0.127^{* * *}$ & $0.143^{* * *}$ & $0.146^{* * *}$ & $0.108^{* * *}$ \\
Sig level & $(0.041)$ & $(0.042)$ & $(0.044)$ & $(0.041)$ \\
& 0.32 & 0.33 & 0.68 & 0.41 \\
& 2.35 & $5.45^{*}$ & $18.48^{* * *}$ & $5.62^{*}$ \\
& 0.309 & 0.066 & 0.000 & 0.060
\end{tabular}

HAC robust standard errors in parentheses *,**,***-Significant at $10 \%, 5 \%$ and $1 \%$ level 
Table 9: Regressions of expansion on contraction depth, stock price, bank loans, risk spread, and residential investment 1920-2007

\begin{tabular}{lccc}
\hline Variable & & & \\
\hline Constant & $5.016^{* * *}$ & $3.851^{* *}$ & $3.574^{* * *}$ \\
& $(1.238)$ & $(1.573)$ & $(1.337)$ \\
$C_{A m p}$ & $-1.051^{* * *}$ & $-1.104^{* * *}$ & $-0.914^{* * *}$ \\
& $(0.064)$ & $(0.223)$ & $(0.115)$ \\
Spread & & 2.194 & $-2.970^{* * *}$ \\
& & $(1.400)$ & $(0.856)$ \\
Stock & & $14.029^{* * *}$ & $14.873^{* * *}$ \\
& & $(5.242)$ & $(4.311)$ \\
Loan & & 6.333 & 1.677 \\
& & $(17.866)$ & $(12.669)$ \\
ResInv & & & $7.616^{* * *}$ \\
& & & $(2.247)$ \\
$\mathrm{N}$ & 16 & 16 & 16 \\
$R^{2}$ & 0.84 & 0.91 & 0.93
\end{tabular}

HAC robust standard errors in parentheses $*, * *,{ }^{* * *}$-Significant at $10 \%, 5 \%$ and $1 \%$ level 
Business Cycle Peak: March 1882

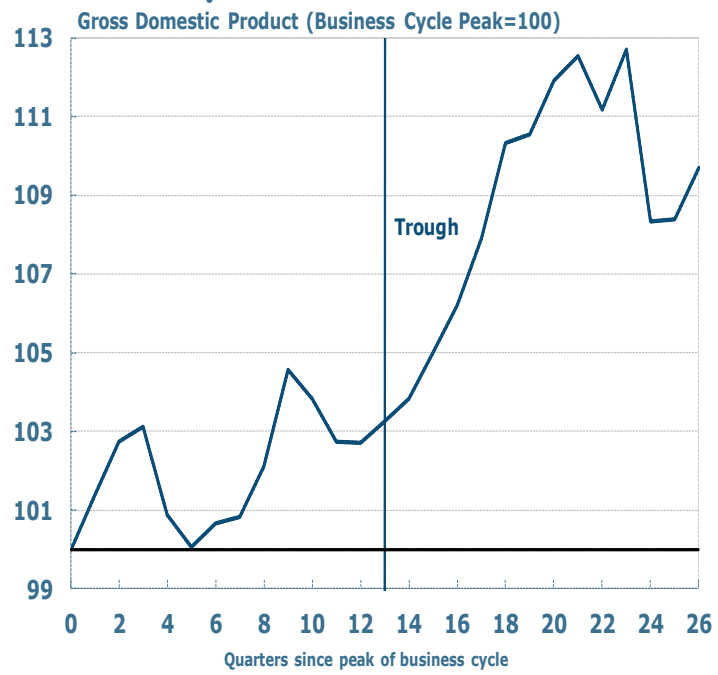

Business Cycle Peak: July 1890

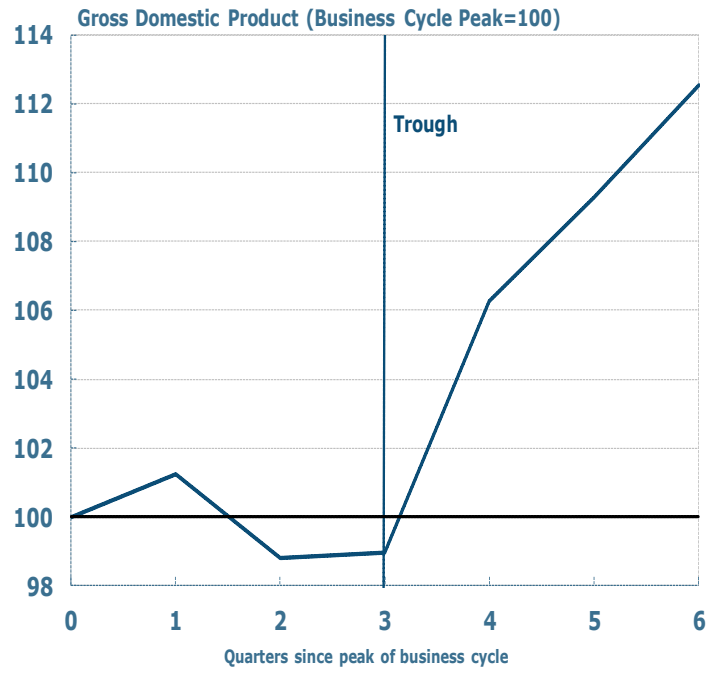

Business Cycle Peak: December 1895

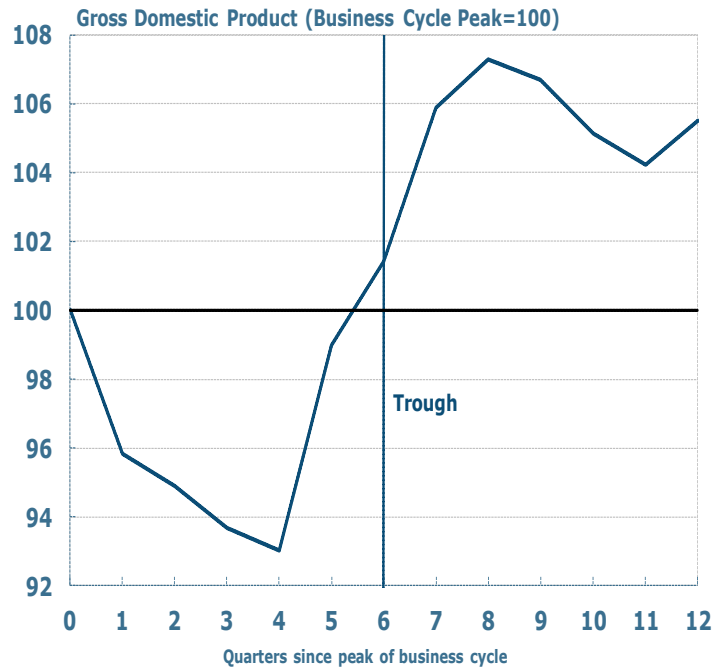

Business Cycle Peak: March 1887

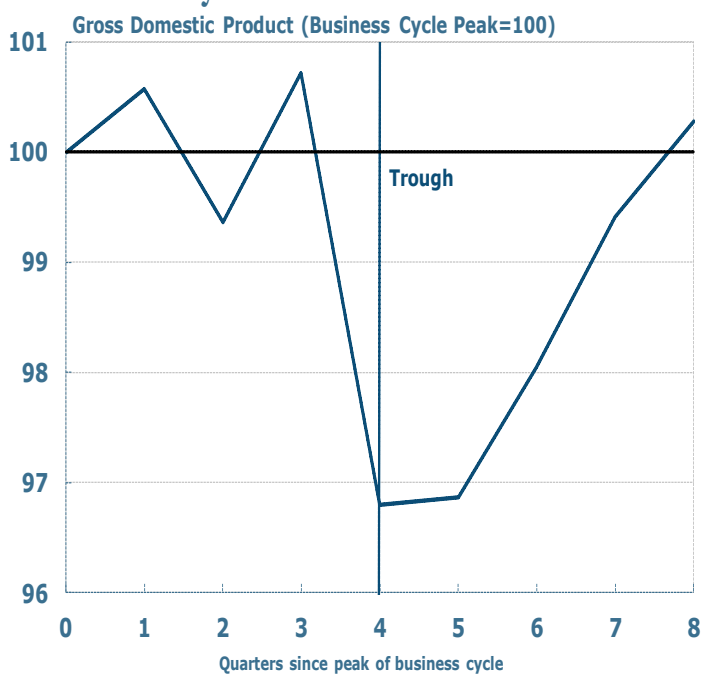

Business Cycle Peak: January 1893

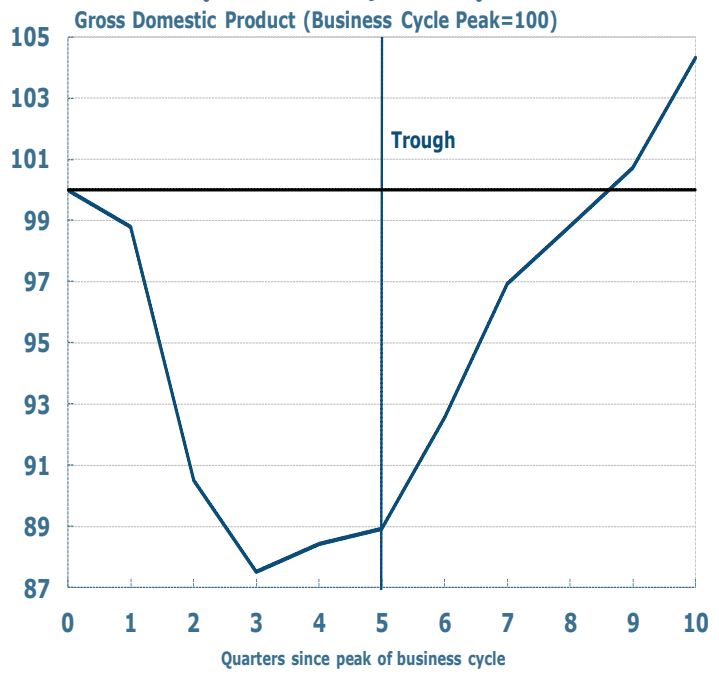

Business Cycle Peak: June 1899

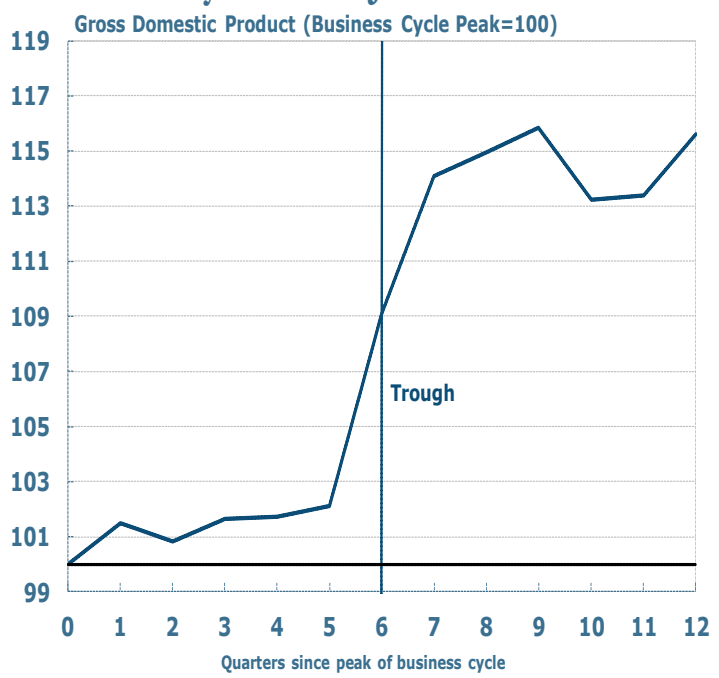




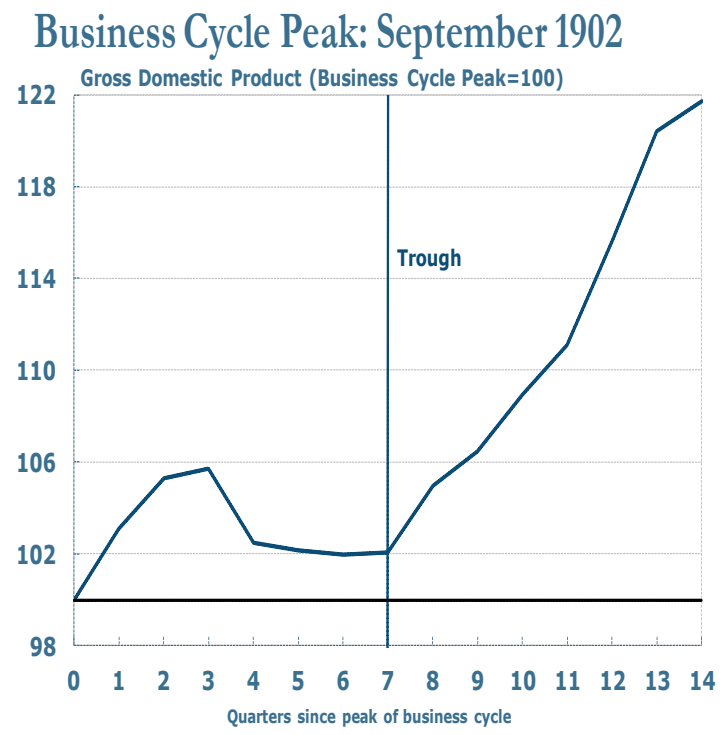

Business Cycle Peak: May 1907

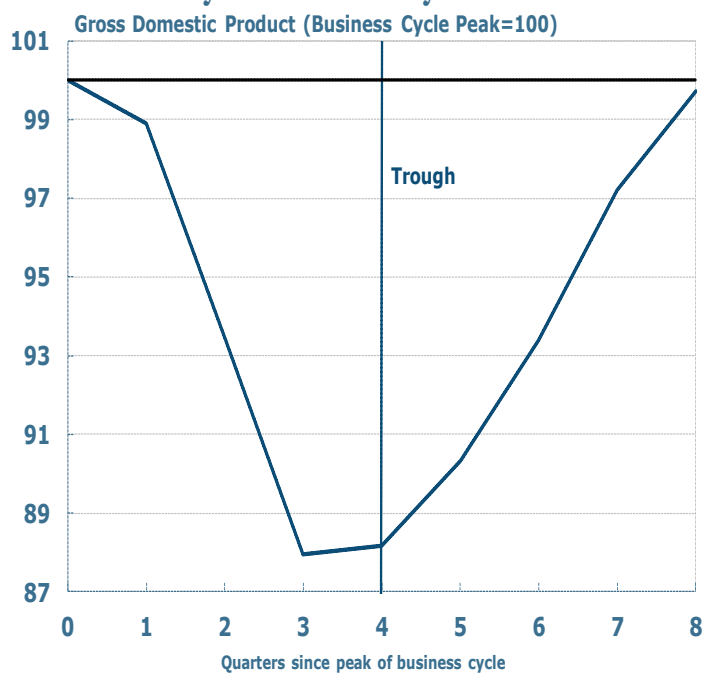

Business Cycle Peak: January 1910
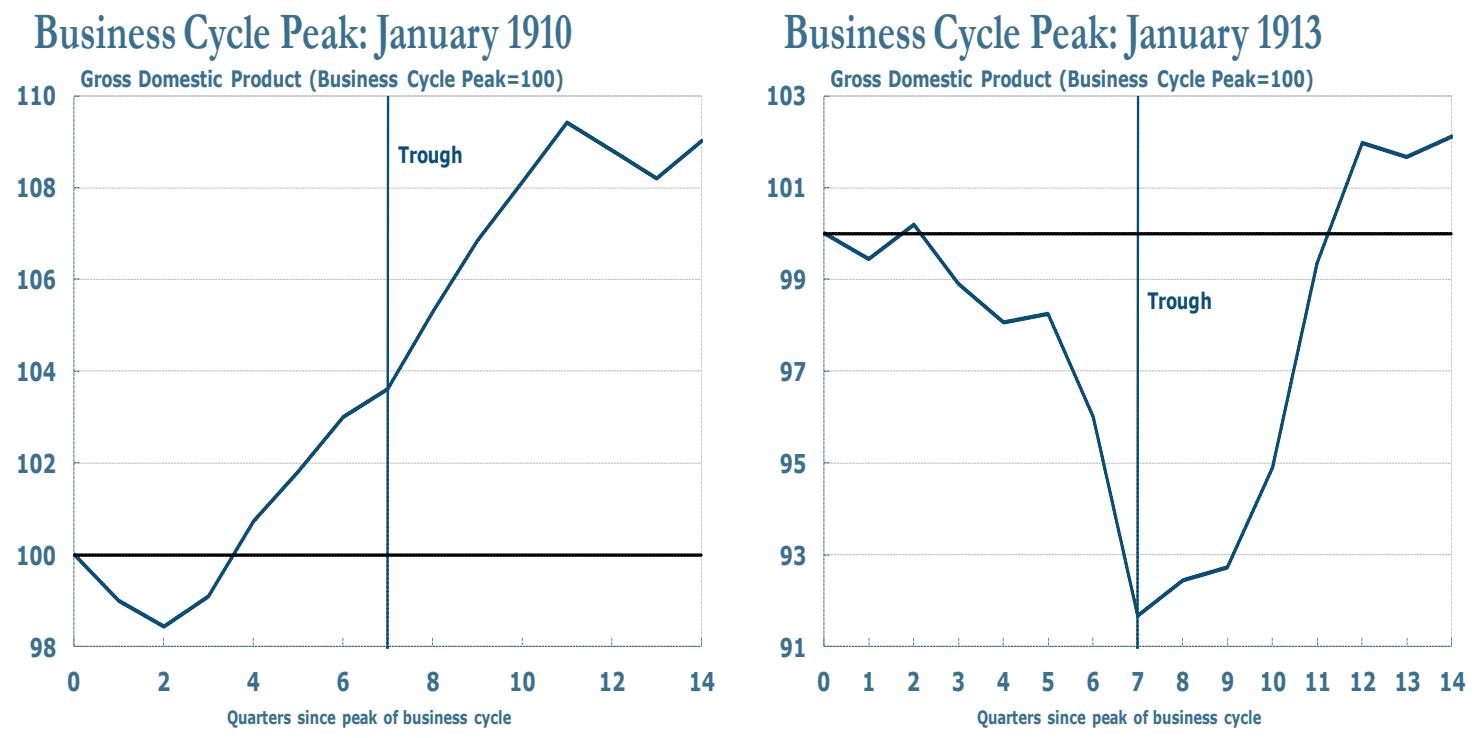

Business Cycle Peak: August 1918

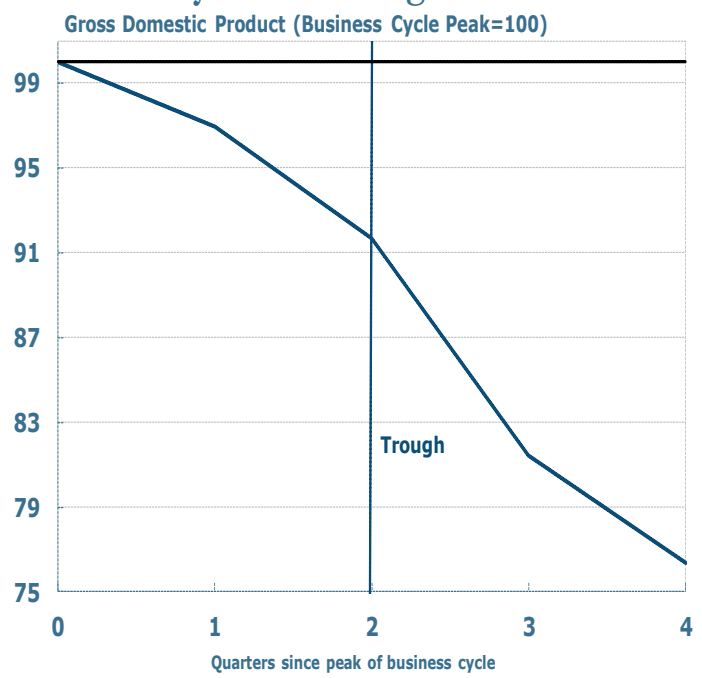

Business Cycle Peak: January 1920

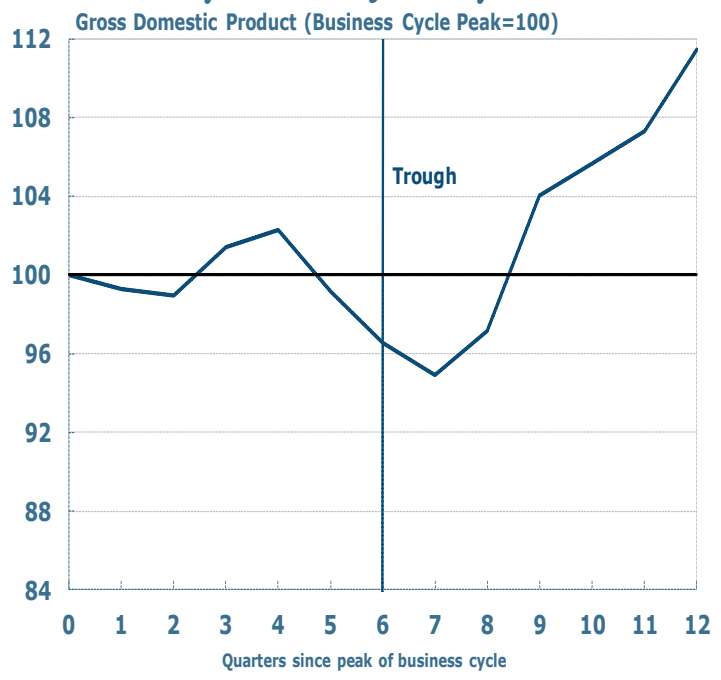


Business Cycle Peak: May 1923

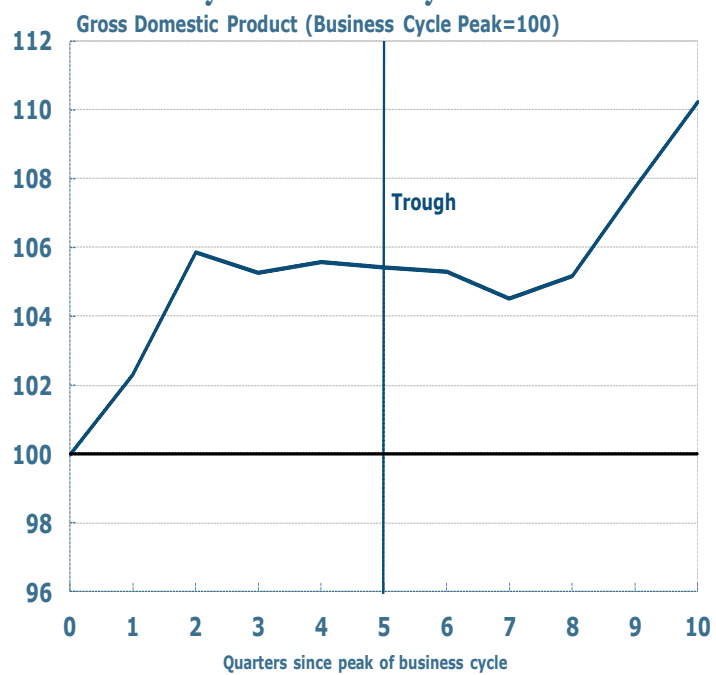

Business Cycle Peak: August 1929

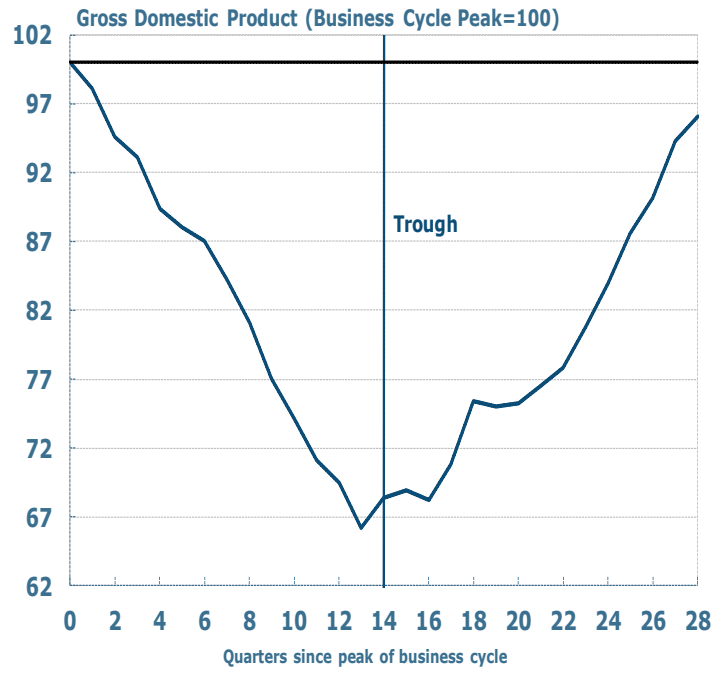

Business Cycle Peak: February 1945

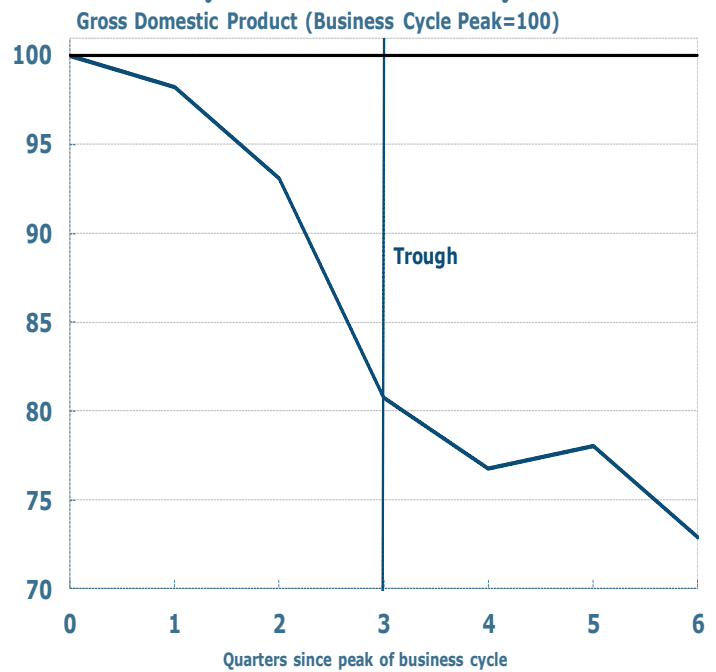

Business Cycle Peak: October 1926

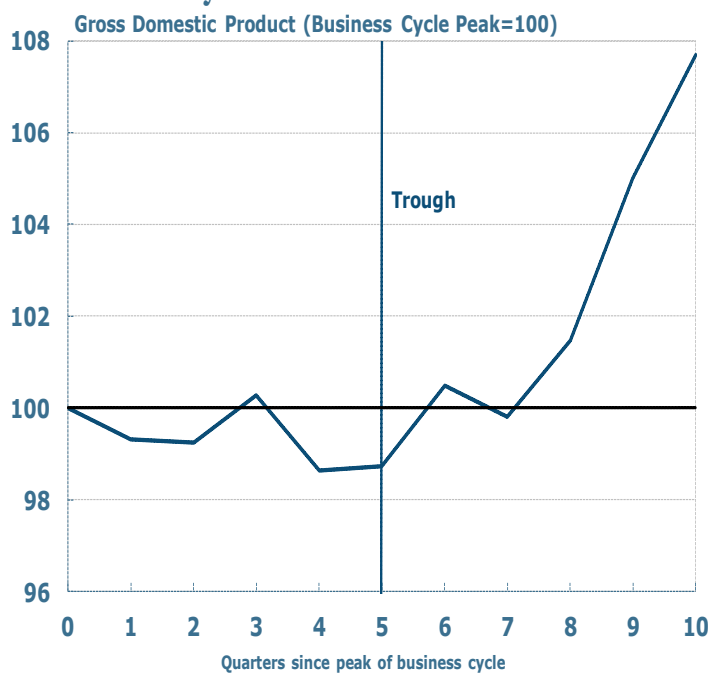

Business Cycle Peak: May 1937

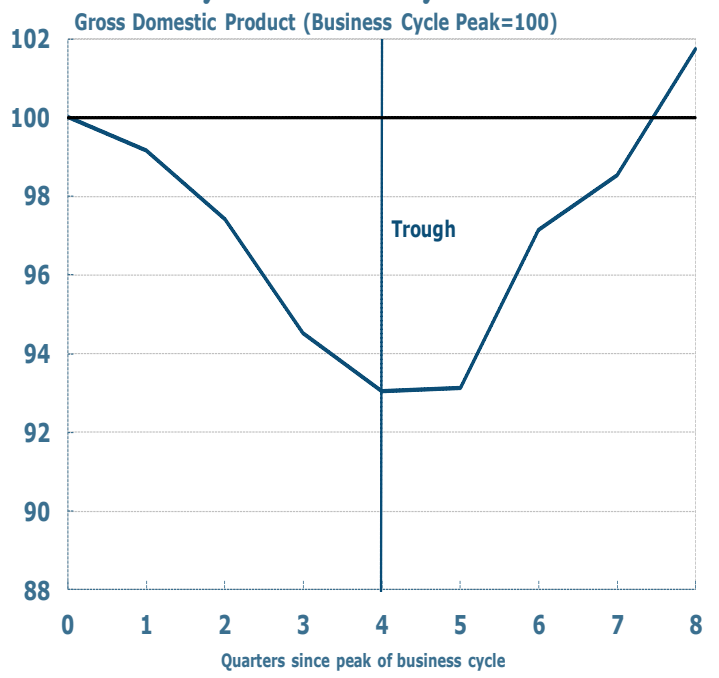

Business Cycle Peak: November 1948

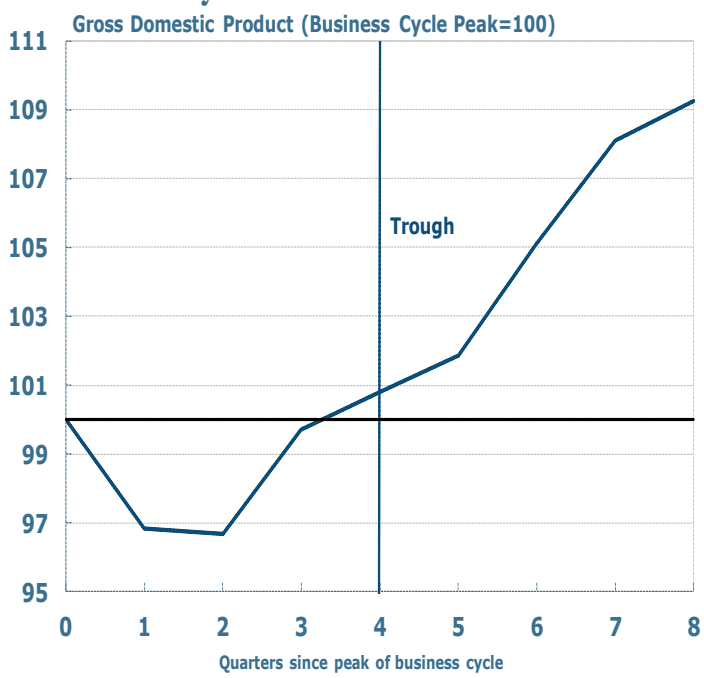


Business Cycle Peak: July 1953

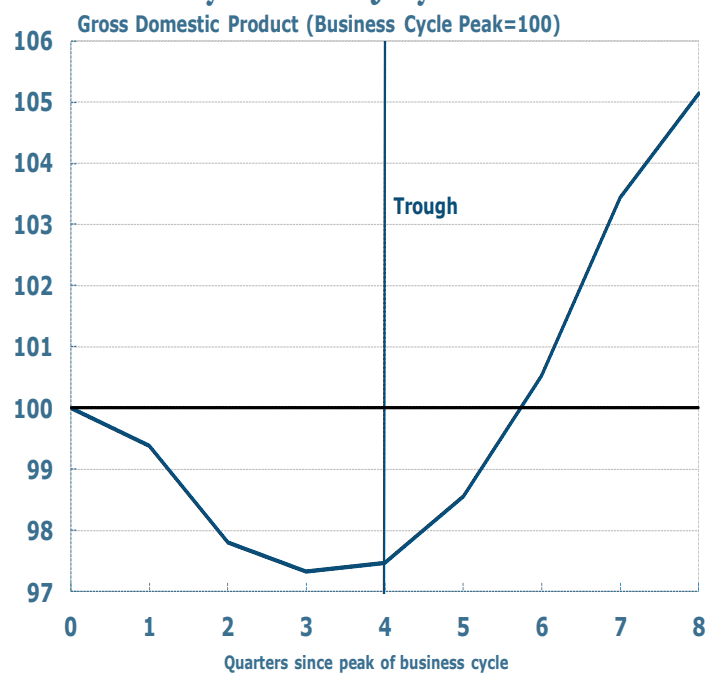

Business Cycle Peak: April 1960

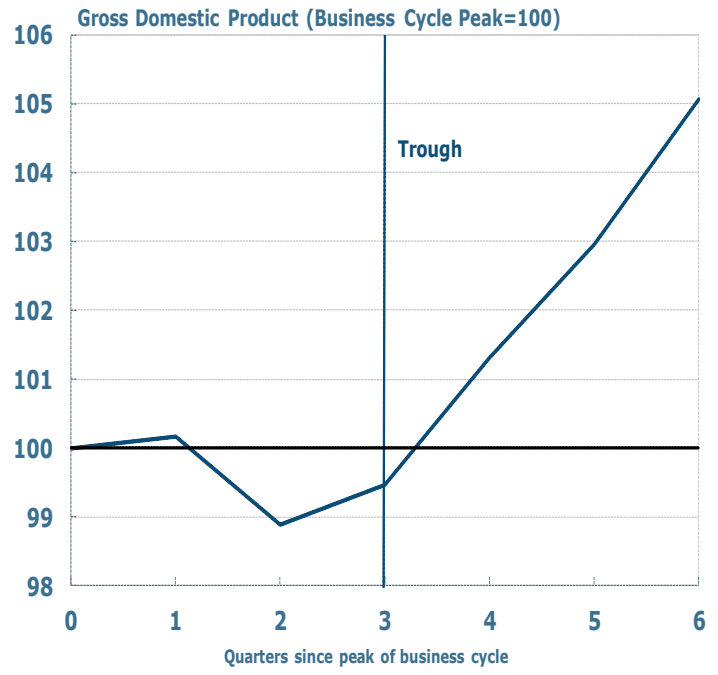

Business Cycle Peak: November 1973

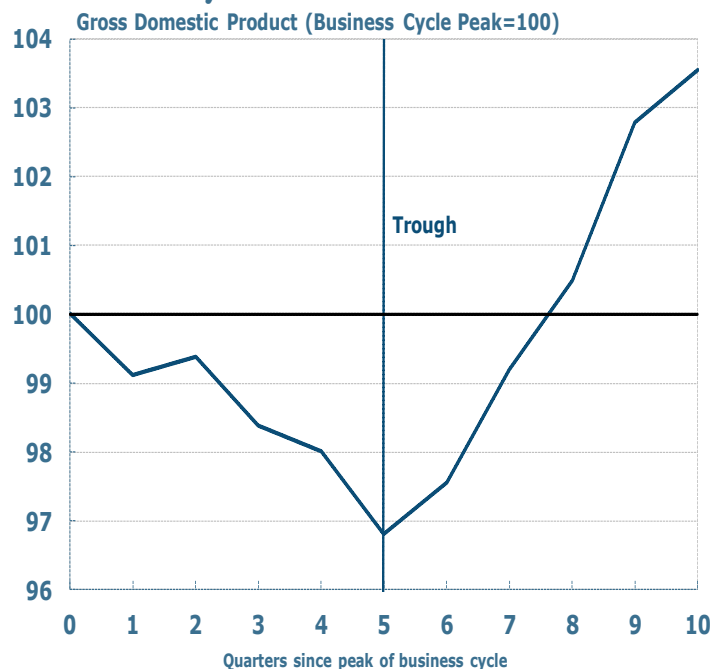

Business Cycle Peak: August 1957

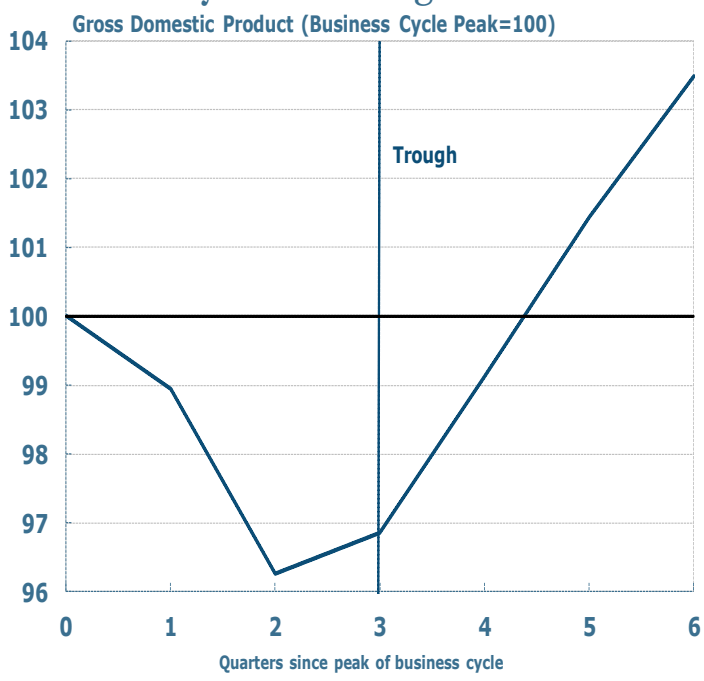

Business Cycle Peak: December 1969

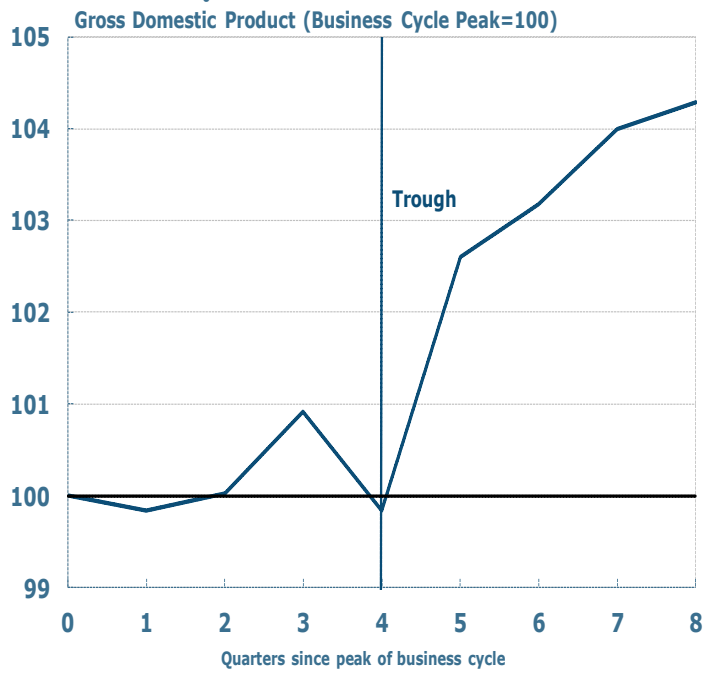

Business Cycle Peak: January 1980

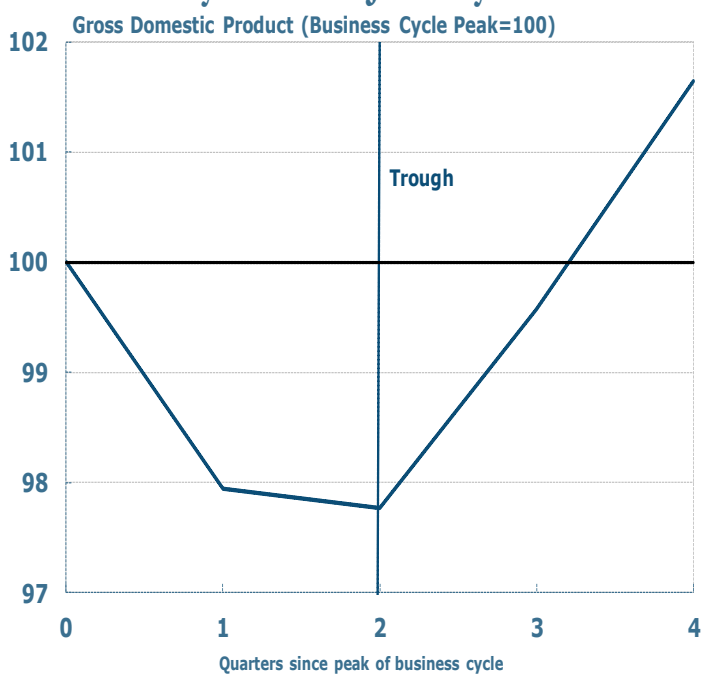




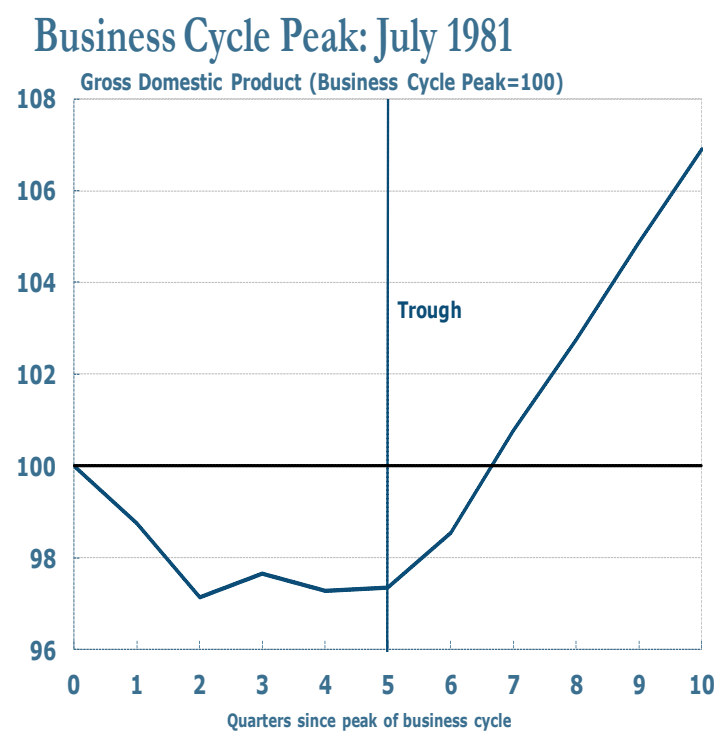

Business Cycle Peak: July 1990

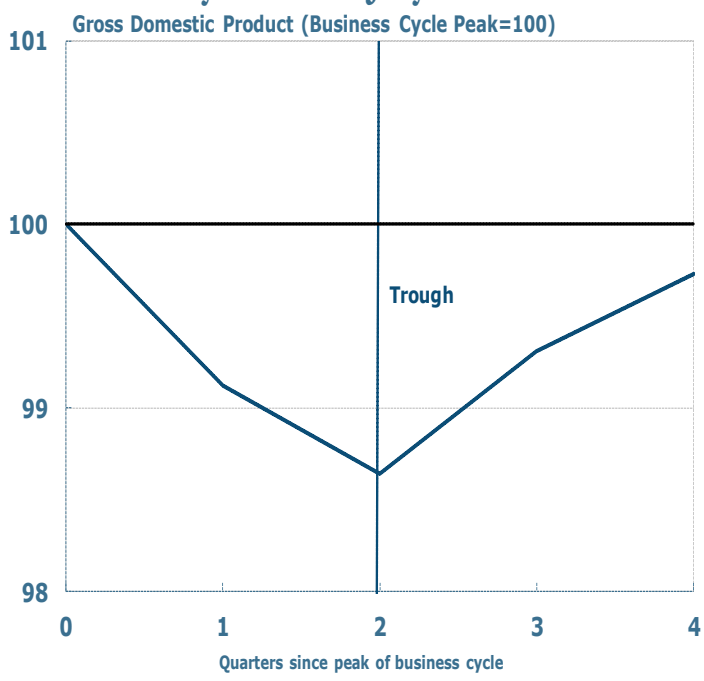

Business Cycle Peak: March 2001

Business Cycle Peak: December 2007
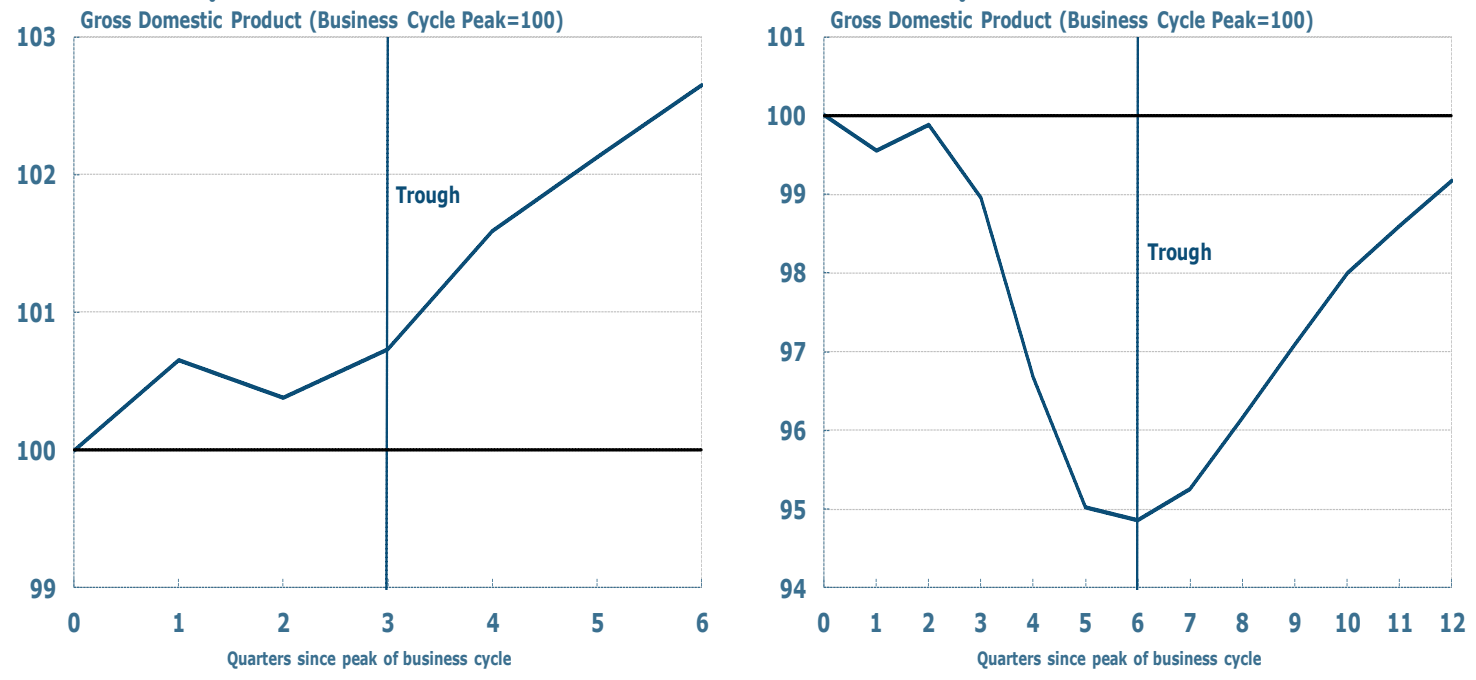

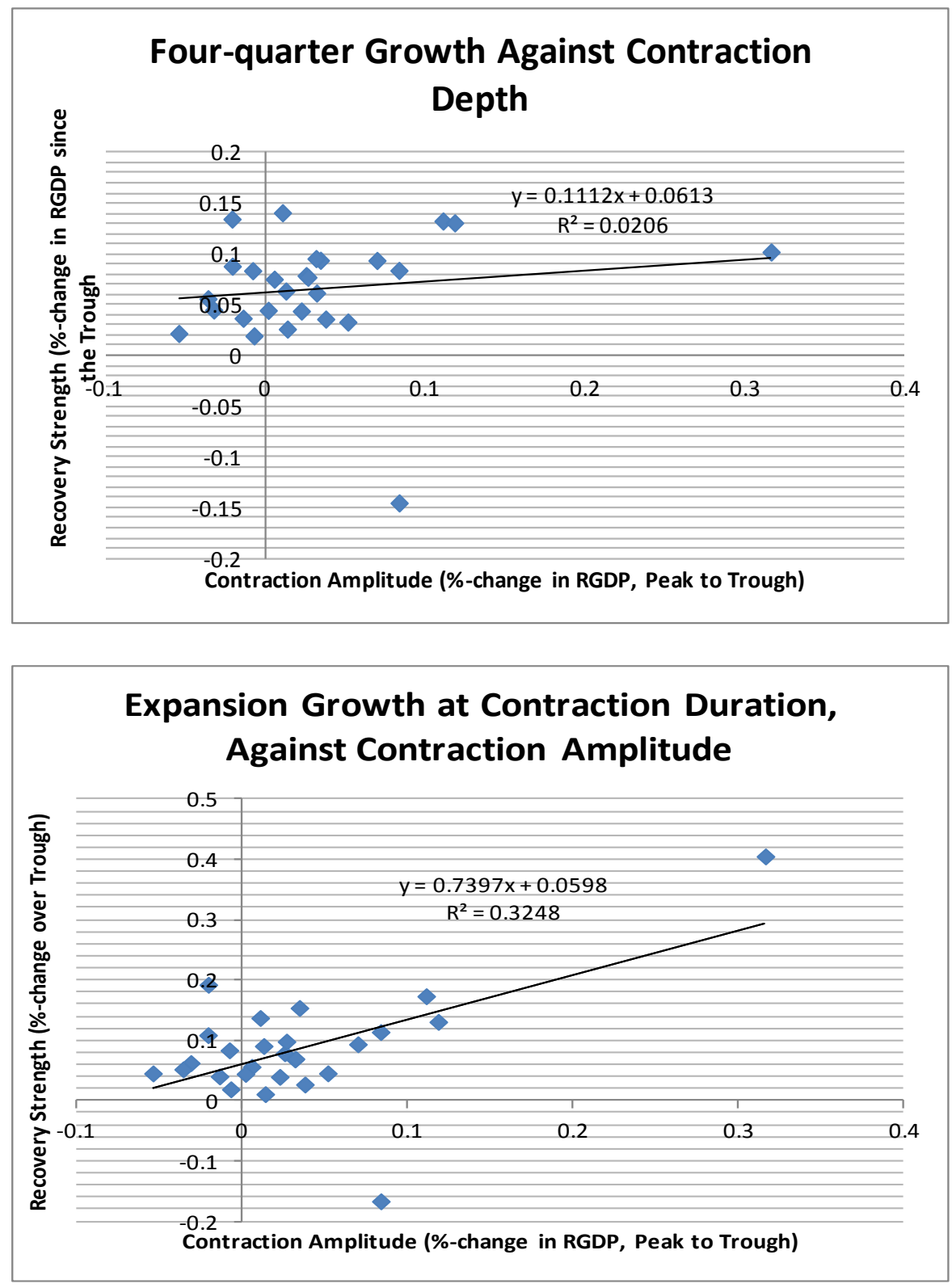

Figure 2: Expansion growth: all cycles. 

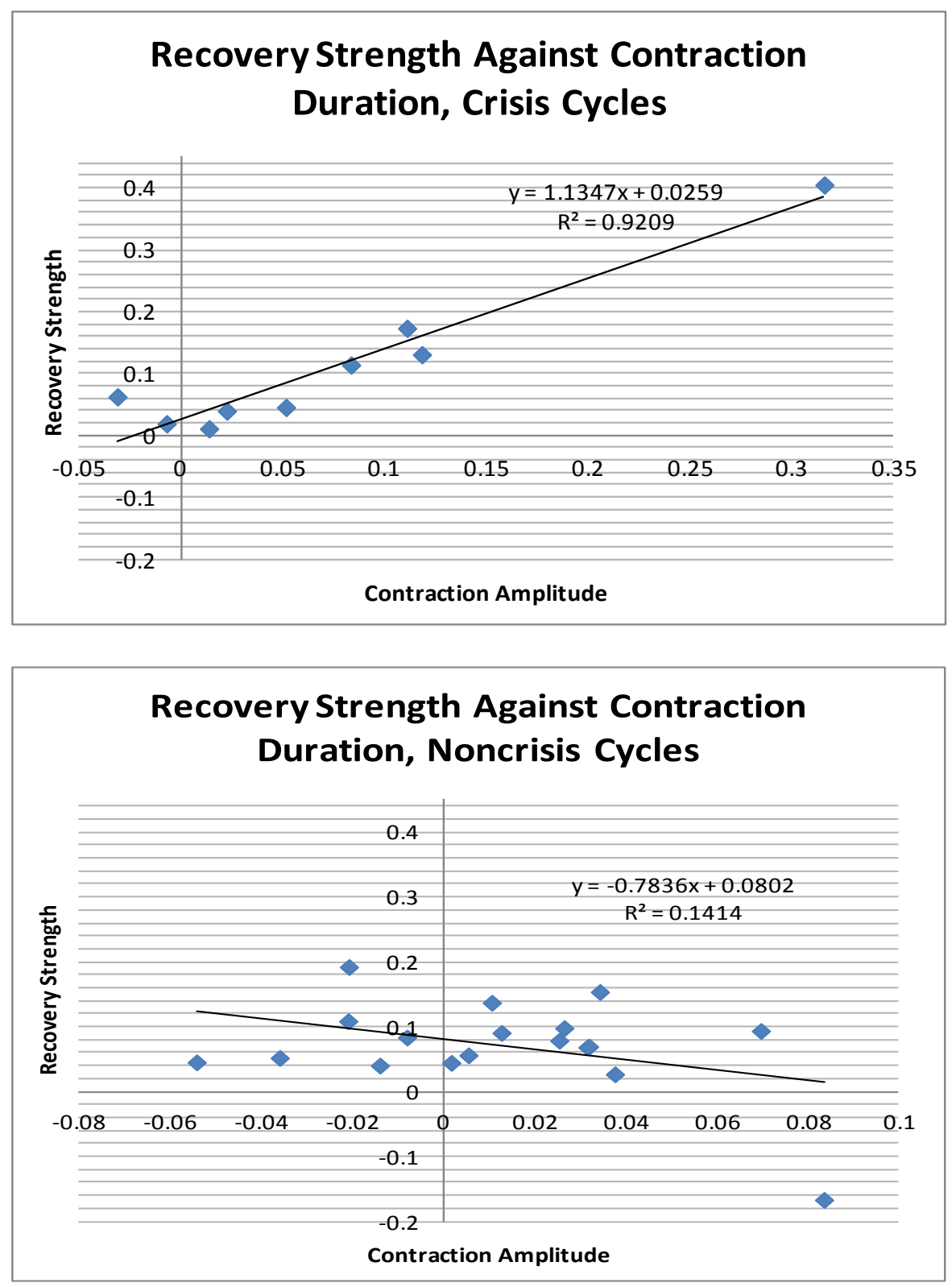

Figure 3: Crisis and Non-Crisis Cycles. 


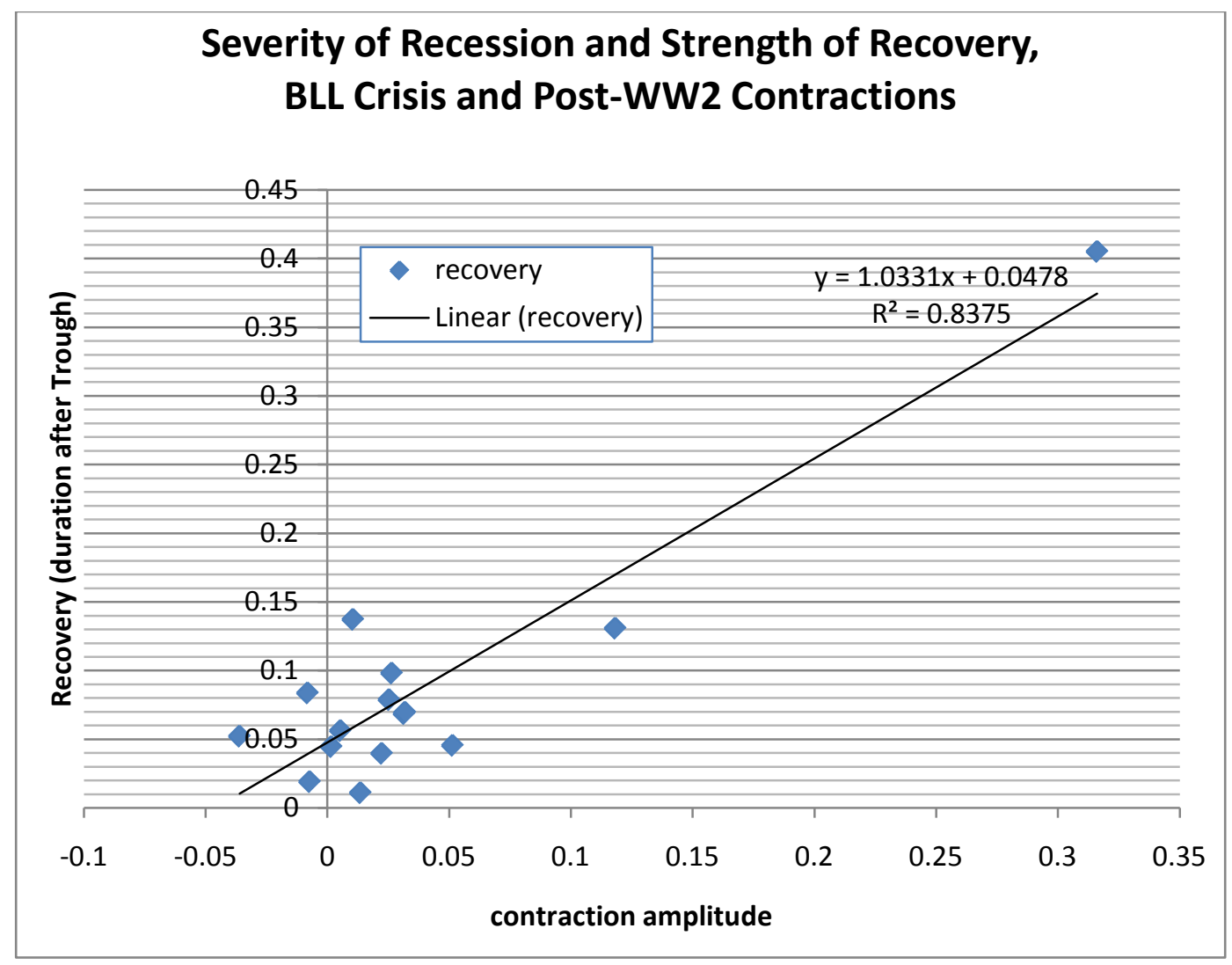

Figure 4: Post World War two contractions and Bordo Landon-Lane contractions 

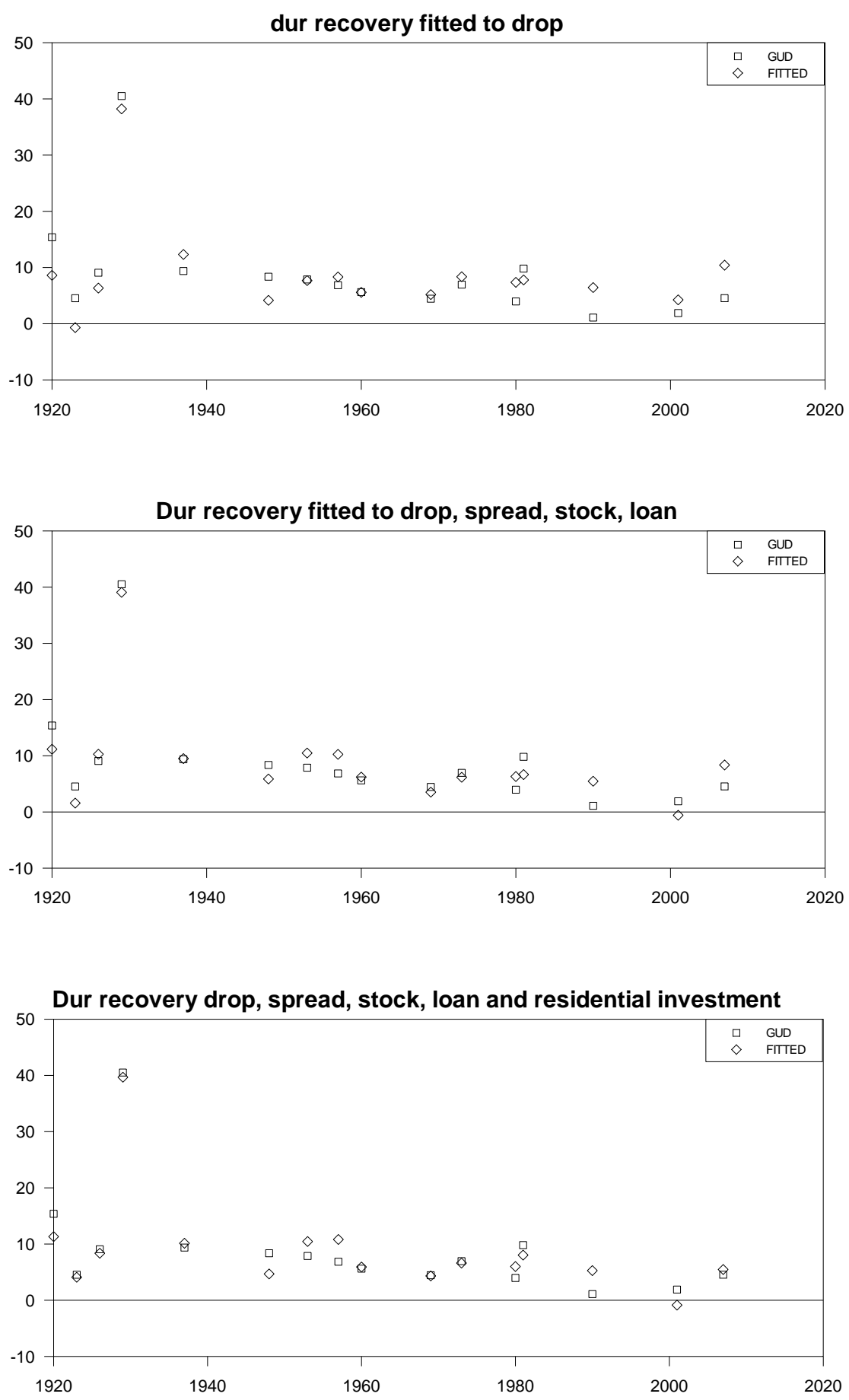

Figure 5: Actual and Fitted Values, Duration Recovery 


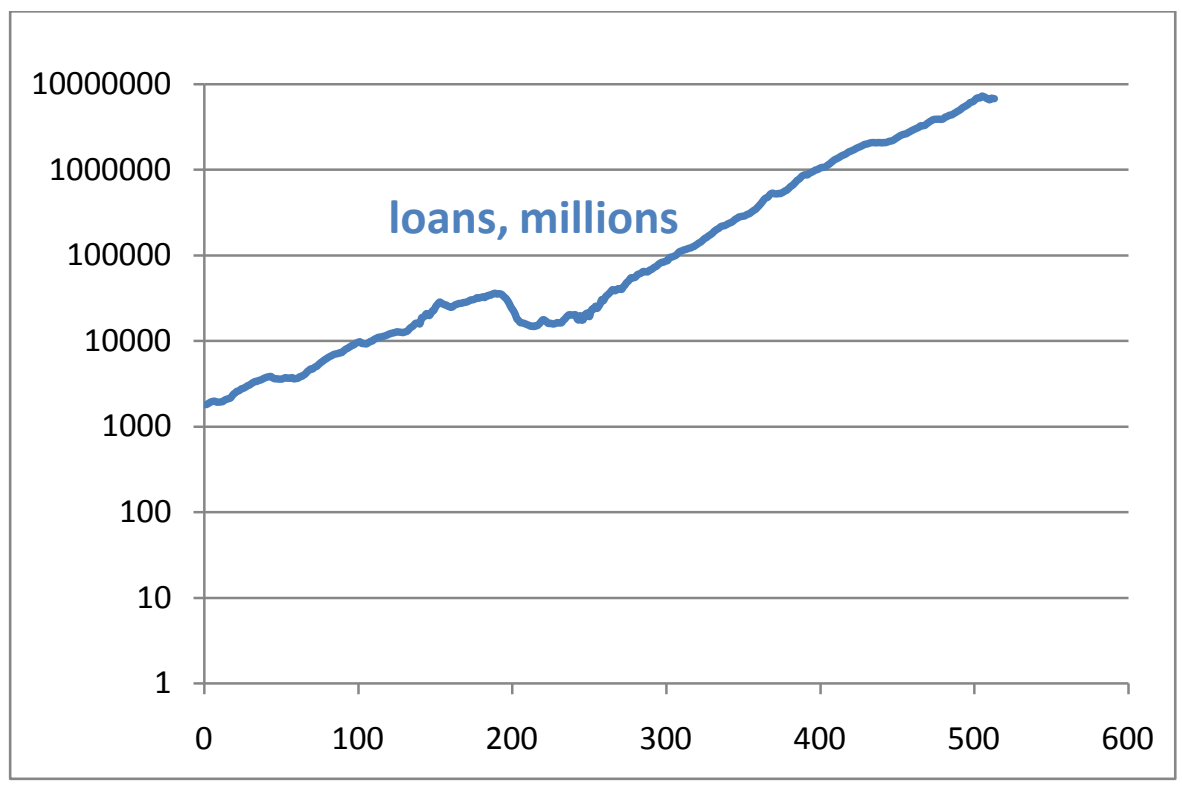

Figure A1: Bank Lending, on a log scale. 